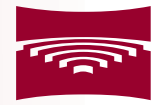
Rīgas STRADina UNIVERSITĀTE

\title{
Dace Žentina
}

\section{Bioḳīmisko un onkoloğisko marķieru diagnostiskā nozīme malignu pleiras eksudātu diferencēšanā no citas etiologiijas šḳidruma pleiras dobumā}

Promocijas darba kopsavilkums zinātniskā doktora grāda "zinātnes doktors (Ph.D.)" iegūšanai

Nozare - medicina Apakšnozare - pneimonoloǵija Rīga, 2020 


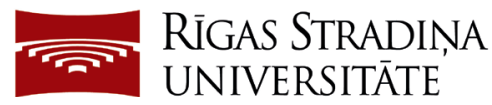

\author{
Dace Žentiņa \\ ORCID 0000-0002-5148-7010
}

\begin{abstract}
Bioķīmisko un onkologisko marķieru diagnostiskā nozīme malignu pleiras eksudātu diferencēšanā no citas etioloǵijas šķidruma pleiras dobumā
\end{abstract}

Promocijas darba kopsavilkums zinātniskā doktora grāda "zinātnes doktors (Ph.D.)" iegūšanai

Nozare - medicīna

Apakšnozare - pneimonoloǵija

Rīga, 2020 
Promocijas darbs izstrādāts Rīgas Stradiña universitātes Iekšḳ̄igo slimību katedrā.

Darba zinātniskie vadītāji:

Dr. med., LZA īstenais loceklis, profesors Aivars Lejnieks,

Rīgas Stradina universitāte, Latvija

Dr. med. asociētais profesors Alvils Krams, Latvijas Universitāte

Oficiālie recenzenti:

Dr. med. asociētā profesore Jūlija Voicehovska,

RSU Iekšḳīgo slimību katedra, Latvija

Dr. med. profesors Valdis Pīrāgs, Latvijas Universitāte

$M D, F C C P$, asociētais profesors Arschang Valipour,

Karla Landšteinera Plaušu slimību un plaušu onkoloǵijas pētniecības

institūts; Florisdorfas Ziemeḷu slimnīca, Vīne, Austrija

Promocijas darbs tiks aizstāvēts attālināti 2020. gada 29. maijā plkst. 15.00 Zoom platformā

Ar promocijas darbu var iepazīties RSU bibliotēkā un RSU tīmekḷa vietnē http://www.rsu.lv/promocijas-darbi

Promocijas padomes sekretāre:

Dr. med. asociētā profesore Inga Stuḳēna 


\section{SATURS}

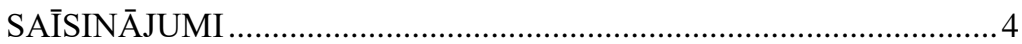

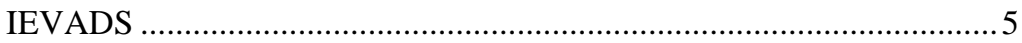

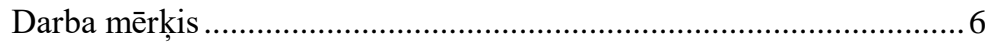

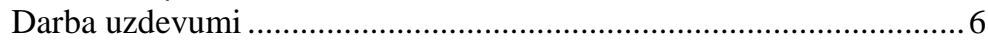

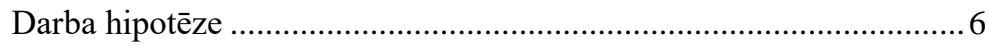

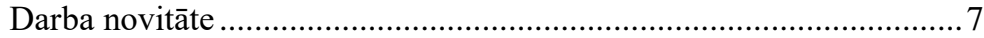

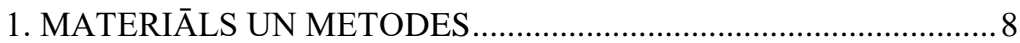

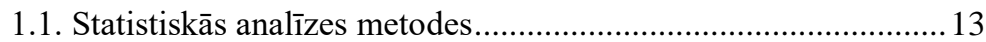

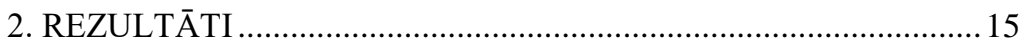

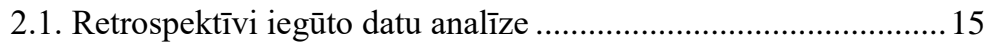

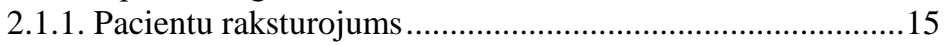

2.1.2. Izmeklējumu rezultāti un diagnozes ...................................15

2.2. Prospektīvi iegūto datu analīze .............................................. 19

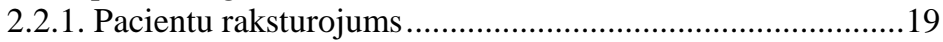

2.2.2. Pleiras šķidruma etiolog̣ijas raksturojums ..........................19

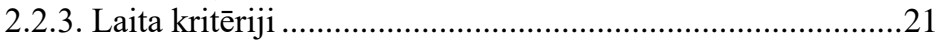

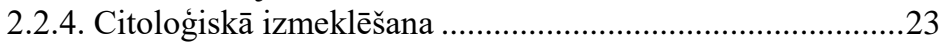

2.2.5. Bakteriologiskā analīze .....................................................23

2.2.6. Audzēju marķieri ............................................................23

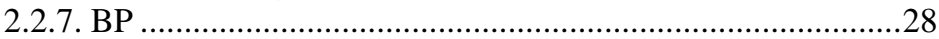

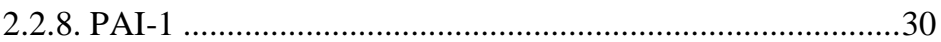

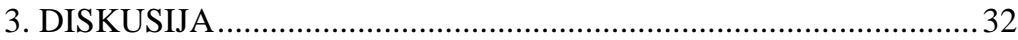

3.1. Pleiras šķidruma epidemiologija un etiologija .......................... 32

3.2. Pleiras šķidruma diagnostikas metodes .......................................36

3.2.1. Bioḳīmiskās izmeklēšanas metodes .......................................38

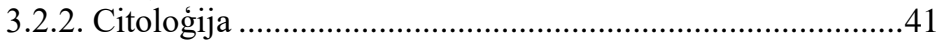

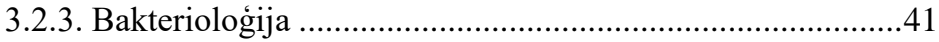

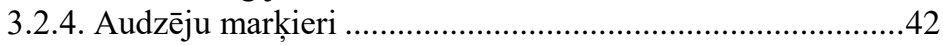

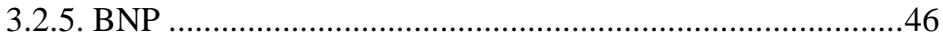

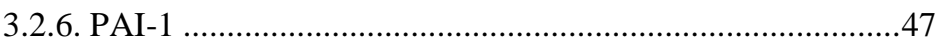

3.3. Pētījuma rezultātus ietekmējoši faktori ........................................ 49

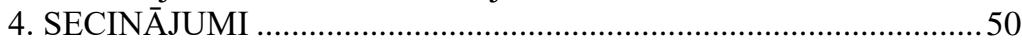

5. PRAKTISKĀS REKOMENDĀCIJAS ….........................................51

6. IZMANTOTĀS LITERATŪRAS SARAKSTS...............................52

7. PUBLIKĀCIJAS PAR PĒTİJUMA TĒMU .......................................56

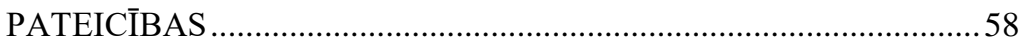




\section{SAĪSINĀJUMI}

$\begin{array}{ll}\text { ADA } & \text { adenozīndezamināze } \\ \text { BNP } & \text { smadzeņu natrijurētiskais peptīds (brain natriuretic peptide) }\end{array}$

CA 125 vēža karbohidrāta antigēns 125

CA 19-9 vēža karbohidrāta antigēns 19-9

CA 15-3 vēža karbohidrāta antigēns 15-3

CEA karcinoembrionālais antigēns

DT datortomogrāfija

HU Hounsfîlda vienības

LDH laktātdehidrogenāze

MPE maligns pleiras eksudāts

MMN monomorfnukleārās šūnas

NT-proBNP $\mathrm{N}$ termināla pro-nātrijurētiskais peptīds ( $N$-terminal pro-brain natriuretic peptide)

NT-proBNP $\mathrm{N}$ termināla pro-nātrijurētiskais peptīds ( $N$-terminal pro-brain natriuretic peptide)

PAI 1 plazminogēna aktivatora inhibitors 1

PATE plaušu artērijas trombembolija

PET pozitronu emisijas tomogrāfija

PMN polimorfnukleārās šūnas

RAKUS Rīgas Austrumu klīniskā universitātes slimnīca

ROC līkne receiving operating characteristics līkne

US ultrasonogrāfija

VATS videoasistēta torakoskopija 


\section{IEVADS}

Pleiras eksudāts - saturs pleiras dobumā, kas rodas iekaisuma, malignu šūnu proliferācijas un/vai patolog̣iski izmainītas kapilāru caurlaidības dēl - ir bieža dažādu slimību komplikācija, tā iemesli galvenokārt ir ḷaundabīgie audzēji, pneimonija un tuberkuloze. Kaut gan plaši epidemioloǵiskie pētījumi nav pieejami, tomēr pēc esošās literatūras datiem visbiežākie cēloṇi šķidrumam pleiras dobumā ir kardiāls hidrotorakss un maligns pleiras eksudāts, bet trešais biežākais iemesls ir parapneimonisks pleirīts (Marel et al., 1993; Zablockis et al., 2002; Valdes et al., 1996; Broadus et al, 2016). Dažādas etiologijas pleiras škidrumu ārstēšana un prognoze būtiski atšķiras, tāpēc ir svarīgi katrā gadījumā precizēt etiologiiju. Kardiāla hidrotoraksa diagnostika klīniskajā praksē grūtības parasti nesagādā, bet MPE diagnosticēt var būt sarežǵīti, it sevišķi apstākḷos, kad ne visur ir pieejama torakoskopija patologisko audu materiāla iegūšanai un tālākai histologiskai analīzei. Tāpēc ne tikai pasaulē, bet arī Latvijā ir svarīgi meklēt citas pieejamus, relatīvi lētus marķierus šo pleiras eksudātu diagnostikai.

Plaušu slimību speciālistu klīniskajā praksē maligni pleiras eksudāti ir bieži sastopama un ne vienmēr viegli risināma problēma. Šobrīd pasaulē nav daudz rekomendāciju taktikai pleiras šḳidruma gadījumos - pēdējās ir 2018. gada Amerikas torakālās asociācijas Malignu pleiras eksudātu vadlīnijas (FellerKopman, 2018), 2014. gada spāṇu vadlīnijas (Villena Garrido et al., 2014) un 2010. gada Britu torakālās asociācijas vadlīnijas, ko izstrādājusi Pleiras slimību vadlīniju grupa (Du Rand I., Hooper C., MuccDuff A., Roberts M.E., Davies H.E., Rahman N.M., Havelock T. et al., 2010). Konvencionālās metodes - pleiras dobuma satura klīniska, bioḳīmiska un citologiska izmeklēšana, ne vienmēr ir pietiekami informatīvas, lai àtri un ticami precizētu pleiras eksudāta etiologiju un izvēlētos tālākās diagnostiskas un ārstēšanas metodes, tāpēc Eiropas Respiratorās savien̄ibas (European Respiratory Society) un Amerikas Torakālās asociācijas (American Thoracic Society) 2001. gada ziņojumā par malignu 
pleiras eksudātu ārstēšanas taktiku kā viens no izpētes virzieniem šin̄̄ jomā tiek rekomendēta jaunu maligna eksudāta marķieru identifikācija (Antony et al., 2001). Promocijas darbā meklēta atbilde uz jautājumiem, vai ar papildus bioḳīmisko un onkologiisko marḳieru palīdzību varētu uzlabot MPE diagnostiku Latvijā.

\section{Darba mērḳis}

Noskaidrot, vai iespējams uzlabot malignu pleiras eksudātu diagnostiku, izmantojot papildus bioḳīmiskos un onkoloǵiskos marḳierus.

\section{Darba uzdevumi}

1. Izanalizēt pieejamo literatūru par šķidrumu pleiras dobumā, tā diagnostiku un diferenciāldiagnostiku.

2. Noskaidrot dažādas etioloǵijas pleiras šḳidruma, tai skaitā malignu pleiras eksudātu, pacientu skaitu SIA RAKUS “Gaiḷezers” iekšḳīgo slimību nodaḷās viena gada laikā.

3. Izpētīt klīniskajā praksē lietotās pleiras eksudātu diagnostiskas metodes

4. Noskaidrot, vai izmantojot papildus bioḳīmiskos (PAI-1, BNP) un onkologiskos (CEA un CA 125) marḳierus, palielinās pleiras punktāta laboratoro izmeklēšanas metožu jutība malignu pleiras eksudātu diferencēšanā.

5. Formulēt šḳidruma pleiras dobumā diagnostikas rekomendācijas.

\section{Darba hipotēze}

1. Papildus bioḳīmisko un onkologiisko marķieru koncentrācijas noteikšana pleiras dobuma šḳidrumā būtiski uzlabo malignu pleiras eksudātu diferencēšanu no citas etiolog̣ijas šķidruma pleiras dobumā. 


\section{Darba novitāte}

Līdz šim Latvijā nav zinātniski analizēti dati par pacientiem, kam stacionārā konstatēta pleiras patologija. Darbā pētìta fibrinolītisko parametru (PAI-1), kā arī audzēja marķieru koncentrācijas serumā un pleiras eksudātā līdz šim neskaidrā nozīme pleiras patoloğijas diagnostikas un ārstēšanas algoritmā. 


\section{MATERIĀLS UN METODES}

Pētījuma protokols apstiprināts RSU Ētikas komitejā. Pētījums veikts SIA Rīgas Austrumu klīniskās universitātes slimnīcas stacionārā "Gaiḷezers".

Lai noskaidrotu, cik pacientu ar šķidrumu pleiras dobumā gada laikā tiek ārstēti SIA RAKUS Stacionāra “Gaiḷezers" iekšḳ̄igo slimību nodạ̣ās, retrospektīvi analizētas to pacientu medicīniskās kartes, kuri no 2010. gada 1. janvāra līdz 2010. gada 31. decembrim ārstējušies un izrakstīti vai miruši no RAKUS slimnīcas “Gaiḷezers” iekšķīgo slimību profila nodaḷām. Atlasītas medicīniskās kartes, kurās izrakstīšanās diagnozē bija norādes par škiidrumu pleiras dobumā. Atlasītās medicīniskās kartes analizētas pēc orğināli izveidotas shēmas (skat 4.1. tabulu!).

1.1. tabula

\section{Slimības vēsturu izvērtēšanas shēma}

\begin{tabular}{|c|c|}
\hline Nr.p.k. & Parametrs \\
\hline 1. & Nodal̦as profils \\
\hline 2. & Gultasdienu skaits \\
\hline 3. & Stacionēšanas mēnesis \\
\hline 4. & Dzimums \\
\hline 5. & Vecums \\
\hline 6. & Vai pacients izrakstīts dzīvs vai miris? \\
\hline 7. & Kurā krūšu kurvja pusē konstatēts škiidrums? \\
\hline 8. & Vai veikta krūšu kurvja rentgenogramma? \\
\hline 9. & Krūšu kurvja rentgenogrammas atradne? \\
\hline 10. & Vai veikta datortomogrāfija plaušām? \\
\hline 11. & Vai veikta US pleiras dobumam? \\
\hline 12. & Vai veikta pleiras dobuma punkcija? \\
\hline 13. & Kurā dienā pēc iestāšanās veikta pleiras dobuma punkcija? \\
\hline 14. & Cik reizes veikta pleiras dobuma punkcija? \\
\hline 15. & Vai veikta klīniskā pleiras dobuma škiidruma analīze? \\
\hline 16. & Ja jā, kāds ir leikocītu sastāvs? \\
\hline 17. & Vai noteikts pleiras dobuma LDH? \\
\hline 18. & Ja jā, kāds ir rezultāts? \\
\hline 19. & Vai noteikts olbaltumvielu līmenis pleiras punktātā? \\
\hline 20. & Ja jā, kāds rezultāts? \\
\hline
\end{tabular}


1.1. tabulas nobeigums

\begin{tabular}{|c|c|}
\hline Nr. p.k. & Parametrs \\
\hline 21. & Vai pleiras dobuma škidrums nosūtīts uz citoloǵisko analīzi? \\
\hline 22. & Ja jā, vai konstatēta malignitāte? \\
\hline 23. & Vai pleiras škidrums izmeklēts bakteriologiski? \\
\hline 24. & Ja jāa kāds rezultāts? \\
\hline 25. & Kādi papildizmeklējumi ir veikti? \\
\hline 26. & Kāda ir izrakstǐšanās pamatdiagnoze? \\
\hline 27. & $\begin{array}{l}\text { Kāda ir pleiras šķidruma etioloǵija pēc izrakstīšanās } \\
\text { diagnozes? }\end{array}$ \\
\hline 28. & Kādi ir primārie audzēji MPE gadījumos? \\
\hline
\end{tabular}

Ar mērḳi noskaidrot papildus bioķīmisko un onkoloǵisko marḳieru nozīmi MPE diagnostikā, prospektīvi tika analizēti no 08.08.2011. līdz 13.06.2014. Rīgas Austrumu klīniskās universitātes slimnīcas stacionāra “Gaiḷezers” Iekšḳīgo slimību klīnikas 2. Pulmonoloǵijas nodaḷā secīgi stacionēti pacienti ar šķidrumu pleiras dobumā.

Iekḷaušanas kritēriji:

- rentgenologiiski un ultrasonsokospiski konstatēts škidrums pleiras dobumā;

- diagnostiskas un/vai terapeitiskas indikācijas pleiras dobuma punkcijai;

- parakstīta informētā piekrišana iegūto datu iekḷaušanai pētījumā.

Par pleiras dobuma punkcijas indikācijām tika uzskatītas:

1. Neskaidras etiologijijas šḳidrums pleiras dobumā, t.sk., aizdomas par MPE;

2. Parapneimonisks pleirīts, t.sk., aizdomas par empiēmu pacientiem ar akūtu slimību, febrilu temperatūru, paaugstinātiem iekaisuma rādītājiem (CRO līmenis) un pneimonijas rengenoloǵisko ainu;

3. Liela apjoma škidrums pleiras dobumā elpas trūkuma mazināšanai (Huggins et al., 2011; Roberts et al, 2010, Havelock et al., 2010) . Pētījumā netika iekḷauti: 
- atkārtoti stacionēti pacienti ar šķidrumu pleiras dobumā;

- pacienti ar dekompensētas sirds mazspējas klīniku (zināma sirds slimība anamnēzē, progresējošs elpas trūkums, perifēras tūskas, sirds mazspējas pazīmes ehokardiogrammā (ehoKG), sastrēgums mazajā asinsrites lokā krūšu kurvja rentgenogrammā) un kardiālu hidrotoraksu, kuriem nebija ne diagnostisku, nedz arī terapeitisku indikāciju pleiras dobuma punkcijai.

Pleiras dobuma punkcija tika izdarīta pēc pacienta informētās piekrišanas pleiras dobuma punkcijai saņemšanas lokālā anestēzijā ar Sol. Lidocaini 2\%, izmantojot Pleurocan (Braun) pleiras dobuma katetrus. Visu pacientu pleiras dobuma šķidruma paraugi tika nosūtīti uz laboratoriju, lai analizētu sekojošus parametrus:

- Citoloǵiskās punktāta analīzes:

- Leikocītu sastāvs (neitrofīlo leikocītu un limfocītu procentuālais sastāvs, hematokrīts);

○ citologiskā analīze (ḷaundabīgu šūnu esamība);

- Bioķīmiskās analīzes:

○ LDH;

○ olbaltumvielas;

○ BNP;

- PAI 1.

- Onkologisko marķieru analīze;

○ CEA;

- CA 125 ;

Visiem pacientiem vienlaicīgi ar pleiras dobuma punkciju tika veikta perifērās vēnas punkcija un paņemti venozie asins paraugi sekojošu parametru noteikšanai:

- $\mathrm{LDH}$; 
- olbaltumvielas;

- BNP;

- PAI-1.

- onkoloǵisko marḳieru analīze;

- CEA;

○ CA 125;

LDH un olbaltumvielu noteikšanai pleiras šķidrums un venozās asinis tika savāktas stobrinos bez antikoagulanta un nosūtītas uz RAKUS Laboratoriskās medicīnas centru Stacionārā "Gaiḷezers". Olbaltumvielas noteiktas ar kolorimetrisko metodi. LDH noteikta ar kinētisko ultravioleto metodi. Pēc rezultātu saṇemšanas ar mērḳi iedalīt pleiras šķidrumus transudātos un eksudātos tika aprēķināti Laita kritērij (Light et al, 2007):

1. Olbaltums pleiras punktātā / olbaltums serumā $>0,5$;

2. LDH pleiras punktātā / LDH serumā $>0,6$;

3. LDH pleiras punktātā ir > par $2 / 3$ seruma LDH lokālās laboratorijas normas (LDH normas augšējā robeža RAKUS Laboratorijas centrā $=240 \mathrm{U} / \mathrm{L})->160 \mathrm{U} / \mathrm{L}$.

Pleiras punktāta klīniskā analīze tika savākta EDTA stobriṇā un nosūtīta uz RAKUS Laboratorijas centru klīniskai analīzei (manuāli šūnu skaitīšana zem mikroskopa un automatizētā metode):

- gaismas mikroskopā saskaitot 200 šūnas un nosakot limfocītu un neitrofîlo leikocìtu (granulocītu un agranulocītu) procentuālo attiecību;

- ar automatizētām metodēm nosakot polimorfnukleāro un monomorfnukleāro leikocītu procentuālo sastāvu, kā arī hematokrītu un hemoglobīna līmeni.

Citoloǵiskai analīzei $30 \mathrm{ml}$ pleiras šķidrums sterilā traukā tika nosūtīts uz RAKUS Laboratoriskās medicīnas centru citoloǵiskai izmeklēšanai. 
Pacientiem ar akūtu slimību, febrilu temperatūru, paaugstinātiem iekaisuma rādītājiem (CRO līmenis) un pneimonijas rengenologisko ainu tika veikts pleiras punktāta uzsējums.

Audzēja marḳieru noteikšanai pleiras šķidrums un venozās asinis tika savāktas stobriņos bez antikoagulanta, 35 minūtes nostādināti un centrifugēti 10 minūtes ar 3000 rpm, no pleiras škidruma atdalīts supernatants un no asinīm serums, tie sasaldēti $-80^{\circ} \mathrm{lī} \mathrm{dz}$ analīzes veikšanai. CA 125 un CEA tika noteikti ar ELISA (enzyme-linked immunosorbent assay) metodi ar Abbot Architect analizatoru saskaņā ar ražotāja protokolu.

BNP noteikšanai pleiras punktāts un asinis tika savāktas EDTA stobriṇā un nosūtītas uz RAKUS Laboratorijas centru. BNP līmenis tika noteikts ar hemiluminiscences mikrodaliṇu imūnḳīmisko analīzi (CMIA).

PAI-1 noteikšanai venozās asinis un pleiras šḳidrums tika savākts stobriṇos bez antikoagulanta, 45 minūtes nostādināti un centrifugēti $10 \mathrm{~min}$. ar $1000 \mathrm{rpm}$. Supernatants un serums tika atdalīts un sasaldēts $-80^{\circ}$ līdz analīzes veikšanai. PAI-1 tika noteikts ar citometrisko xMAP tehnologiju (Luminex iekārta) Rīgas Stradiṇa universitātes Cilvēka bioḳīmijas un fizioloǵijas katedrā.

Kardiāla hidrotoraksa grupā tika iedalīit pacienti ar iepriekš pierādītu sirds mazspēju un esošām sirds mazspējas pazīmēm (perifēras tūskas, zināma sirds slimība anamnēzē, sirds mazspējas pazìmes ehoKG vai venozs sastrēgums krūšu kurvja rentgenogrammā) un hipoksēmiju zem $93 \% \mathrm{SpO}_{2}$, kura būtiski nelabojās pēc papildus skābekḷa pievades. Pacienti ar parapneimoniskiem pleirītiem tika diagnosticēti pēc sekojošiem kritērijiem: akūta slimība ar klepu, febrilu temperatūru, paaugstinātiem iekaisuma rādītājiem (CRO līmenis) un atbilstošu rentgenoloǵisko atradni. Maligns pleiras eksudāts (MPE) tika diagnosticēts, pamatojoties uz citoloǵisko pleiras punktāta izmeklēšanu. Ja citologiskā izmeklēšana bija negatīva, eksudāts par MPE tika uzskatīts arī gadījumos, ja pacientam bija jau iepriekš pierādīta maligna slimība un netika 
konstatēts cits eksudāta cēlonis (Sahn, 1997). Pacientiem, kuriem klīniskajā pleiras šķidruma analīzē monomorfnukleāro šūnu skaits bija $>95 \%$, tika veikta slēgtā pleiras biopsija. Tuberkuloza pleirīta diagnoze sākotnēji tika pierādīta ar pleiras biopsijas histologisko izmeklēšanu, atrodot specifiskas izmaiņas epiteloīdšūnu granulomas ar kazeozu nekrozi, apstiprinot tās ar bioptāta bakteriologisko izmeklēšanu (uzsējumu acidorezistento baktēriju pierādīšanai). Pleirīts, saistīts ar pankreatītu, tika diagnosticēts pēc paaugstināta lipāzes līmeṇa pleiras šķidrumā.

Pacientiem ar MPE, kuri piekrita talka pleirodēzei, tika veikta talka pleirodēze caur drenu ar $4 \mathrm{~g}$ talka suspensijas un $40 \mathrm{ml} \mathrm{0,9 \%} \mathrm{NaCl}$ šḳīdumu, pievienojot $10 \mathrm{ml}$ 2\% Lidokaīna šḳīdumu. Drena tika slēgta uz 2 stundām un evakuēta pēc tam, kad 2 dienas izdalījās mazāk kā 100 ml šķidruma.

\subsection{Statistiskās analīzes metodes}

Visu datu statistiskie aprēķini tika veikti ar SPSS (Statistical Package for the Social Sciences) for Windows programmas 23.0 versiju un MS Excel 2007. Atbilstoši vispārpieņemtajiem principiem medicīnas statistikā $p$ vērtību 0,05 uzskatīta par divpusējo testu rezultātu statistiskās ticamības slieksni. Personu grupu raksturošanai izmantotas vispārpieņemtās statistikas metodes (Teibe, 2007; Dawson, 2001; Altman, 1997). Kvantitatīvo datu sadalījuma atbilstība normālajam pārbaudīta, izmantojot histogrammas un Kolmogorova-Smirnova testu. Tā kā datu sadalījums neatbilda normālajam sadalījumam, vidējo rādītāju raksturošanai izmantota mediāna, 25. un 75. percentīle. Kategoriskie jeb kvalitatīvie main̄̄gie raksturoti ar procentuālo proporciju. Lai iegūtos rezultātus varētu vispārināt pētāmajai populācijai, aprēḳinātas 95\% ticamības intervāla robežas. Divu neatkarīgu grupu salīdzināšanai izmantots Manna-Vitneja (MannWhitney) testu, jo mainīgie neatbilda normālajam sadalījumam. Kategorisko main̄̄go salīdzināšanai dažādās grupās izmantots Pīrsona (Pearson) hī $\chi 2$ testu, 
veicot arī kontinuitātes korekciju pēc Jeitsa (Yates) metodes un aprēkinātas arī izredžu attiecības (odds ratio, OR). Lai no teiktu dažādu testu jutību un specifitāti izmantotas ROC (abreviatūra no angḷu valodas - receiver operating charasteristic) līkne, aprēķinot zemlīknes laukumu. 


\section{REZULTĀTI}

\subsection{Retrospektīvi iegūto datu analīze}

\subsubsection{Pacientu raksturojums}

Retrospektīvi analizējot medicīniskās kartes, konstatēts, ka no RAKUS Stacionāra "Gaiḷezers" iekšķīgo slimību profila laika posmā no 2010. gada 1. janvāra līdz 2010. gada 31. decembrim izrakstīit 14838 pacienti, un šajās nodaḷās miris 741 pacients (kopā 15588 pacienti).

No visu pacientu stacionāra medicīniskām kartēm atlasītas 716 (4,6\%) ar izrakstīšanās diagnozē minētu jebkuras etiologijas šķidrumu pleiras dobumā. No šiem pacientiem $615(85,9 \%)$ izrakstīti, 101 (14,1\%) - miris. Kopējā mirstība stacionārā bija 4,4\%.

No analizētajiem pacientiem 337 (47\%) bija vīrieši un 379 (53\%) sievietes vecumā no 18 līdz 98 gadiem. Apsekoto pacientu sadalījums pēc vecuma ir unimodāls, modālais vecums 71 līdz 80 gadi. Saslimušo skaita palielināšanās notiek vecumā virs 40 gadiem - vecuma grupās līdz 41 gadam ir tikai 4,2\% no izlasē iekḷautajiem pacientiem, bet pārejās vecuma grupās ir 95,8\% pacientu.

\subsubsection{Izmeklējumu rezultāti un diagnozes}

Analizējot medicīniskajās kartēs dokumentētos izmeklējumus pacientiem ar šķidrumu pleiras dobumā, 651 (90,9\%) pacientam stacionārā bija veikta krūšu kurvja rentgenogrāfija, 11 pacientiem (1,5\%) tā bija veikta ambulatori, bet 54 pacientiem $(7,5 \%)$ - netika veikta. $167(23,3 \%)$ pacientiem bija veikta krūšu kurvja datortomogrāfija. Analizējot abus šos izmeklējumus kopā, 155 pacientiem $(21,6 \%)$ bija veikta gan rentgenogrāfija, gan datortomogrāfija. 494 pacientiem $(68,9 \%)$ bija veikta tikai rentgenogrāfiska izmeklēšana, 11 pacientiem $(1,5 \%)$ - 
tikai datortomogrāfija, 42 pacientiem $(5,9 \%)$ netika veikta ne rentgenogrāfija, ne datortomogrāfija. 141 gadījumā (19,7\% no visiem pētījuma pacientiem) medicīniskajā kartē bija dokumentēta pleiras dobuma ultrasonogrāfija (2.1. attēls). No šiem pacientiem 104 bija veikta pleiras dobuma punkcija, 37 pleiras dobuma punkcija netika veikta. 407 pacientiem (56,8\% no visiem pētījuma pacientiem) medicīniskajā kartē nebija norādes par pleiras dobuma ultrasonogrāfijas veikšanu un nebija veikta pleiras dobuma punkcija. 168 pacientiem (23,5\% no visiem pacientiem) bija veikta pleiras dobuma punkcija, bet nebija minēta pleiras dobuma ultrasonogrāfija.

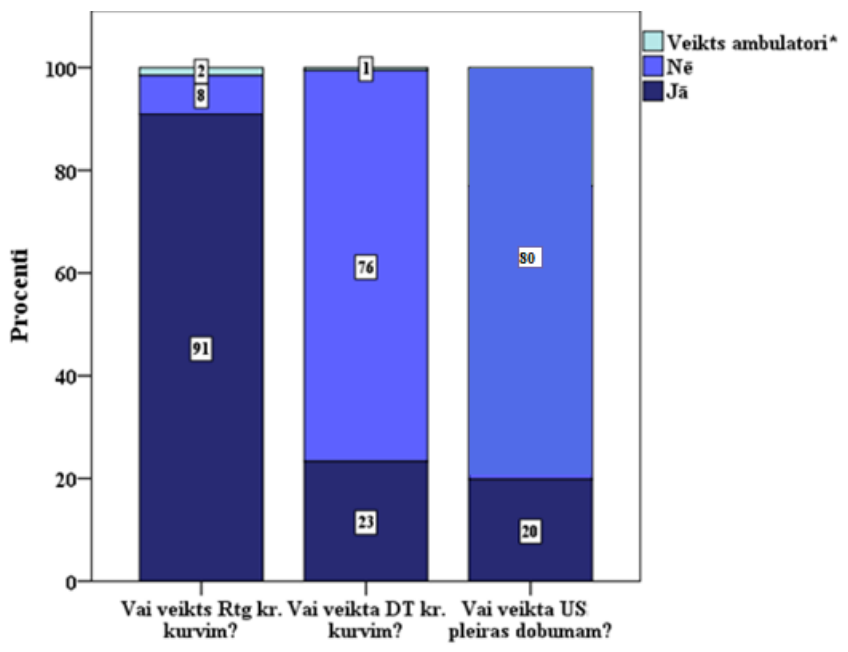

\section{1.att. Attēldiagnostikas izmeklējumi pacientiem ar šḳidrumu pleiras dobumā}

Apkopojot dokumentēto pleiras punktāta laboratoro izmeklēšanu, visbiežāk - 130 gadījumos (47,8\% no punktētajiem pacientiem) - bija noteikta klīniskā analīze, LDH, olbaltumvielas un citolog̣ija. 29 gadījumos (10,7\% no punktētajiem pacientiem) nebija veiktas nekādas pleiras punktāta analīzes 2.2.attēls). 


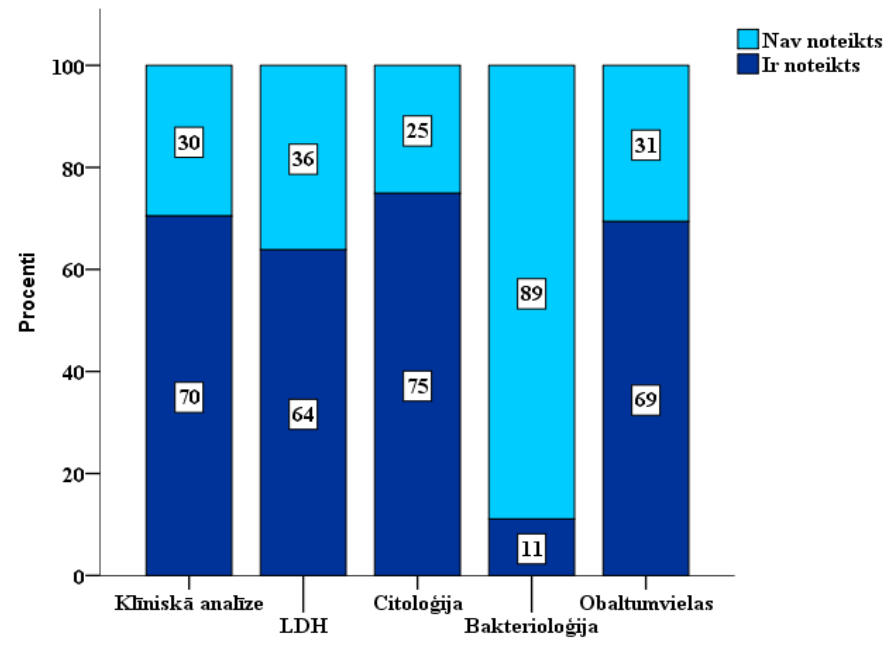

\section{2. att. Procentuālais veikto un neveikto laboratoro pleiras punktāta analīžu sadalījums}

Izvērtējot noteiktās izrakstīšanās diagnozes, 426 (59,5\%) pacientiem šḳidrums pleiras dobumā tika traktēts kā kardiālas hidrotorakss, 103 (14,4\%) pacientiem MPE, $71(9,9 \%)$ - parapneimonisks pleirīts, 30 (4,2\%) pacientiem izrakstīšanās diagnozē bija minēta pleiras empiēma, 11(1,5\%) - hemotorakss, 6 $(0,8 \%)$ - tuberkulozs pleirīts. Citas ǵenēzes šķidrums tika minēts 36 pacientiem (5\%): nefrotisks sindroms 9 gadījumos, aknu ciroze -6 , plaušu artērijas trombembolija -7 , hiperhidratācija hroniskas nieru mazspējas slimniekiem - 6, pēctraumatisks pleirīts - 2, Meigsa sindroms - 1, sistēmas sarkanā vilkēde - 1, jatrogēns hidropneimotorakss -1 , neskaidri formulēta diagnoze -3 gadījumos. 33 pacientiem $(4,6 \%)$ šķidruma veids izrakstīšanās diagnozē nebija precizēts (2.3. attēls). 


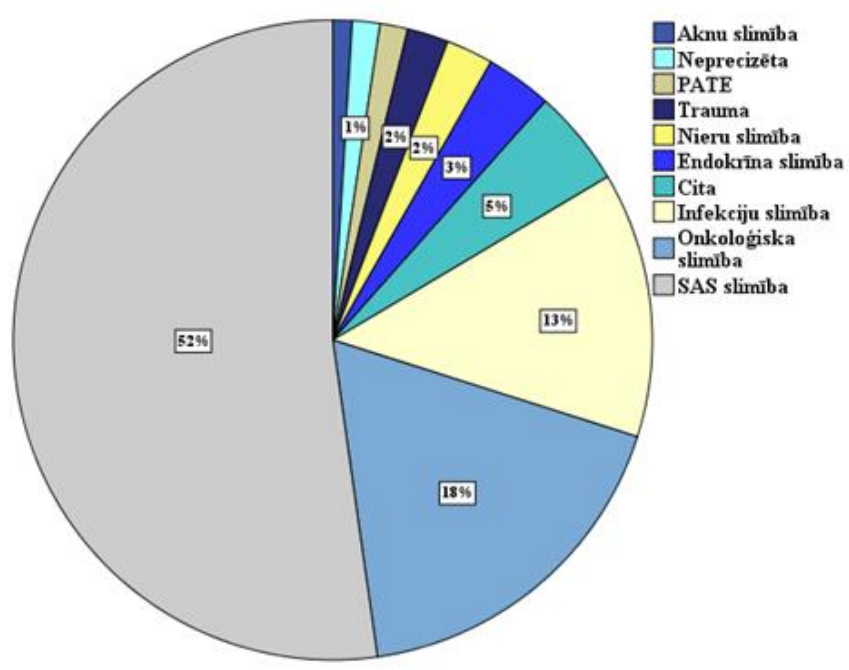

2.3. att. Pacientu $(n=716)$ procentuālais sadalījums pēc izrakstīšanās diagnozēm

Sīkāk analizējot izrakstīšanās diagnozes un pleiras punktāta izmeklējumus, konstatēts, ka 426 (59,5\% no visiem) pacientiem izrakstīšanās diagnozē pleiras šķidrums tika saistīts ar kardiālu mazspēju, no tiem punkcija tika veikta 98 (23\% no kardiāliem hidrotoraksiem). 51 (11,9\%) punktētam pacientam diagnoze apstiprināta ar̄̄ laboratori - LDH līmenis punktātā liecina par transudātu, turpretim $13(3,1 \%)$ punktētajiem pacientiem LDH līmenis liecina par eksudātu. 34 (23\%) pacientiem laboratorie izmeklējumi bija nepietiekami, lai precizētu šķidruma raksturu un etioloǵiju.

103 - 14,4\% no visiem pacientiem izrakstīšanās diagnozē minēts MPE, no tiem 62 (60,2\%) pacientiem veikta pleiras dobuma punkcija un tikai 37 (36\%) pacientiem diagnoze apstiprināta arī citologiski. 8 (7,8\%) pacientiem bija noteikts LDH līmenis, 5 (4,9\%) no tiem tas atbilda transudātam. 17 (16,5\%) pacientiem laboratoriskie izmeklējumi nav bijuši pietiekami, lai noteiktu škiidruma raksturu un etiologiju. 
$71-9,9 \%$ no visiem pacientam izrakstīšanās diagnozē minēts parapneimonisks pleirìts, no tiem 37 (52,1\%) pacientiem veikta pleiras dobuma punkcija. 23 (32,3\%) pacientiem apstiprināts eksudāts, 7 (9,9\%) pacientiem LDH līmenis liecina par transudātu un 7 (9,9\%) nav bijuši pietiekami laboratorie izmeklējumi šķidruma rakstura un etiologijas precizēšanai. Atsevišḳi izdalīta pacientu grupa (30 pacienti - 4,2\%), kam izrakstī̌sanās diagnozē minēta pleiras empiēma. No šīs grupas $12(40 \%)$ pacientiem empiēma konstatēta bakterioloğiski, 15 (50\%) pacientiem bijis eksudāts un 2 gadījumos laboratoriskā izmeklēšana bijusi nepilnīga.

\subsection{Prospektīvi iegūto datu analīze}

\subsubsection{Pacientu raksturojums}

No 08.08.2011. līdz 13.06.2014. SIA RAKUS stacionāra "Gaiḷezers" Iekšķīgo slimību klīnikas 2. Pulmonologijias nodaḷā secīgi tika stacionēti 144 pacienti, kuriem rentgenoloǵiski un ultrasonsokospiski tika konstatēts şḳidrums pleiras dobumā, kuriem bija nepieciešama pleiras dobuma punkcija diagnostiskos un terapeitiskos nolūkos un kuri parakstīja piekrišanu pētījumam un pleiras dobuma punkcijai. 69 (47,9\%) no tiem bija vīrieši. Pacientu vecums bija no 22 līdz 97 gadiem. 136 (94,4\%) pacienti no stacionārā izrakstīiti, bet 8 miruši $(5,5 \%)$.

\subsubsection{Pleiras šķidruma etioloğijas raksturojums}

Tika konstatēts, ka apsekotos pacientus pēc pleiras šķidruma etioloǵijas var iedalīt: kardiālā hidrotoraksa grupā - 42 (29,2\%), 22 (52,3\%) no tiem vīrieši; pacienti; MPE grupā - 67 (46,5\%) pacienti, 21 (31,3\%) no tiem vīrietis;parapneimoniska pleirìta grupā - 27 (18,8\%) pacienti, 19 (70,3\%) no tiem vīrieši. $6(4,1 \%)$ pacientiem konstatēja tuberkulozu pleirītu, $1(0,7 \%)$ 
pacientam pankreatogēnu pleirītu un $1(0,7 \%)$ pacientam PATE ar pleirītu (2.4 attēls). N̦emot vērā mazo tuberkuloza pleirīta, pankreatogēna pleirīta un PATE pacientu skaitu, šie pacienti tālāk analizēti netika.

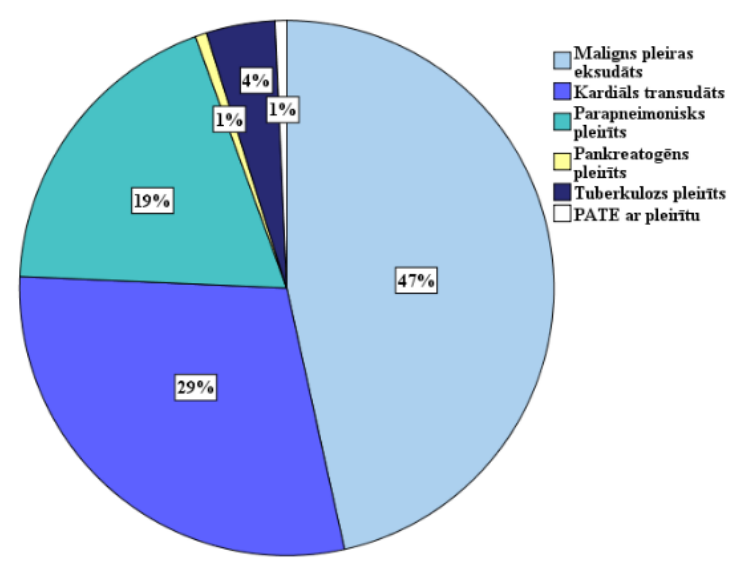

2.4. att. Pleiras šḳidruma etiologiija $(\mathbf{n}=\mathbf{1 4 4})$

MPE grupā 24 (35,8\%) pacientiem bija plaušu vēzis, 14 (20,9\%) pacientēm - olnīcu vēzis, 13 (19,4\%) pacientēm - krūts vēzis, 2 pacientiem nieru vēzis, 2 pacientēm - dzemdes kakla vēzis, 2 pacientiem - kuṇgá vēzis, 1 pacientam - aizkuṇǵa dziedzera vēzis, 1 pacientei - sarkoma, 1 pacientam mezotelioma, 1 pacientam - melanoma, 1 pacientam - prostatas vēzis. 5 pacientiem primāro audzēja lokalizāciju noskaidrot nebija iespējams (2.5. attēls). 


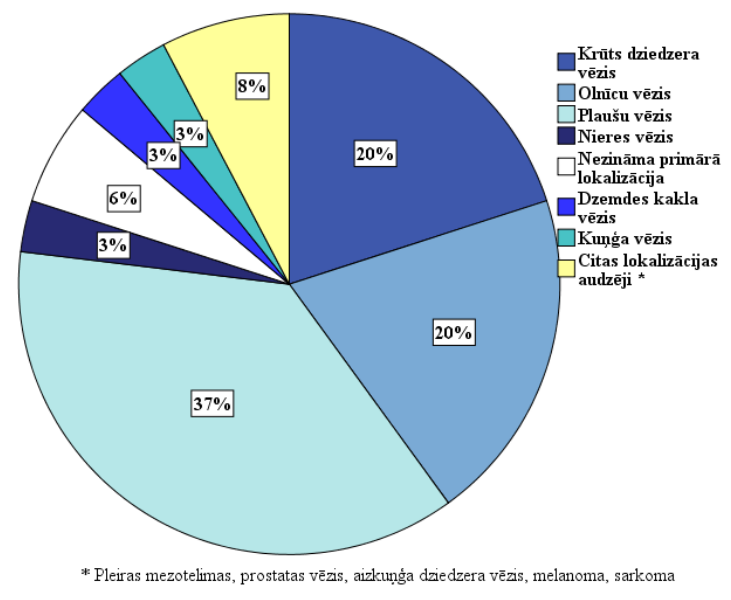

2.5. att. MPE sadalījums atkarībā no primārās audzēja lokalizācijas $(n=67)$

\subsubsection{Laita kritēriji}

\section{Kardiāla hidrotoraksa grupa}

Kardiāla hidrotoraksa grupā tika iedalīti 42 (29,2\%) pacienti ar iepriekš pierādītu sirds mazspēju, vecumā no 50 līdz 92 gadiem, kuriem klīniski vērojamas hroniskas sirds mazspējas dekompensācijas pazīmes.

34 (81\%) pacientiem Laita kritēriji atbilda transudātam, bet 8 (19\%) pacientiem Laita kritēriji atbilda eksudātam (2 pacientiem olbaltumvielas punktātā/olbaltumvielām serumā bija $>0,5 ; 3$ pacientiem LDH punktātā pret LDH serumā bija $>0,6,1$ pacientam LDH bija $>0,6$ un LDH $>160 \mathrm{U} / \mathrm{L}(2 / 3$ no LDH augšējās seruma normas); 3 pacientiem visi Laita kritēriji bija nedaudz paaugstināti. Visiem šiem pacientiem tika noteikts olbaltumvielu gradients. 7 pacientiem tas bija $>31 \mathrm{~g} / \mathrm{L}$, bet 1 pacientam tas bija $<31 \mathrm{~g} / \mathrm{L}$, bet BNP serumā šim pacientam bija 1631 pg/ml. Kardiālā hidrotoraksa grupā izrakstīit 39 (92,9\%) pacienti, bet miruši 3 (7,1\%) pacienti $(2 ., 4$. un 11. stacionēšanas dienā). 


\section{Parapneimoniski pleirīti}

Parapneimonisku pleirītu grupā tika iekḷauti 27(18,6\%) pacienti vecumā no 38 līdz 97 gadiem ar pneimonijas klīnisko ainu: akūta slimība ar klepu, febrilu temperatūru, paaugstinātiem iekaisuma rādītājiem (CRO līmenis) un atbilstošu rentgenologisko atradni. Visiem pacientiem bija pozitīvs vismaz viens Laita kritērijs. 20 (74\%) pacientiem bija pozitīvs pirmais Laita kritērijs, t.i., olbaltumvielu līmenis punktātā pret olbaltumvielu līmeni serumā $>0,5(0,29$ 2,28), 26 (96,3\%) pacientiem bija pozitīvs 2. Laita kritērijs - LDH līmenis punktātā pret LDH līmeni serumā > 0,6 (0,51-54,67) un 27 (100\%) pacientiem bija pozitīvs 3. Laita kritērijs - LDH līmenis punktātā $>2 / 3$ no laboratorijas normas (168-1006 U/L). Visiem pacientiem pleiras dobuma şķidrums izmeklēts mikrobiolog̣iski, bet tikai diviem (7,4\%) identificēta mikroflora: vienam pacientam Klebsiella pneumoniae, vienam pacientam - Staphylococcus sacchrolyticus. 3 pacientiem bija nepieciešama pleiras dobuma drenāža ar fibrinolītisko enzīmu ievadīšanu. Izrakstīti 26 (96,3\%) pacienti, bet miris 1 $(3,7 \%)$ pacients 9 . stacionēšanas dienā.

\section{Maligni pleiras eksudāti}

MPE grupā tika iekḷauti 67 (46,5\%) pacienti vecumā no 40 līdz 90 gadiem. Laita kritēriji bija negatīivi 2 pacientiem (2,9\%). 59 (88\%) pacientiem bija pozitīvs pirmais Laita kritērijs - olbaltmvielus līmenis serumā pret olbaltumvielu līmeni punktātā $(0,510$ - 4,25); 50 (74,6\%) pacientiem bija pozitīvs otrais Laita kritērijs - LDH punktātā pret LDH serumā $>0,6(0,64-9,78)$ un 52 pacientiem $(77,6 \%)$ bija pozitīvs trešais Laita kritērijs - LDH līmenis punktātā > 2/3 no augšèjās laboratorijas normas (163-1908 U/L). Visiem pacientiem pleiras punktāts tika izmeklēts citoloğiski, 45 (67,2\%) pacientiem tika atrastas malignas šūnas. 18 (26,9\%) pacientiem tika veikta talka pleirodēze. 
63 (94\%) pacienti tika izrakstîti, bet 4 (6\%) pacienti nomira, (3., 9., 14. un 22. dienā), t.sk., 1 pacients nomira pēc talka pleirodēzes.

\subsubsection{Citolog̣iskā izmeklēšana}

Malignas šūnas pleiras punktātā atrada 44 (65,7\%) no 67 pacientiem ar MPE. 38 pacientiem $(83,4 \%)$ malignas šūnas atrada pirmajā, bet $6(13,6 \%)$ otrajā pleiras punktāta citoloǵiskās izmeklēšanas reizē.

\subsubsection{Bakterioloǵiskā analīze}

27 pacientiem pleiras punktāts tika nosūtīts mikrobioloǵiskai izmeklēšanai, bet tikai 2 pacientiem uzsējums bija pozitīvs - vienā gadījumā tika identificēta Klebsiella pneumoniae, bet vienā - Staphylococcus saphrolyticus.

\subsubsection{Audzēju marķieri}

\section{CA 125 un CEA}

Lai noskaidrotu, vai eksistē statistiski ticamas CA 125 un CEA atšķirīibas dažādas etiologijas pleiras šķidrumā, tālāk tika analizētas parapneimonisko pleirītu, malignu pleiras eksudātu un transudātu grupas un noteiktas šo audzēju marķieru mediānās vērtības un 25. un 75. percentile serumā un punktātā, kā arī punktāta/seruma attiecība (2.1. tabula). 
2.1. tabula

Mediānais CA-125 un CEA serumā un pleiras šķidrumā pacientiem ar transudātu, malignu eksudātu un parapneimonisku pleirītu

\begin{tabular}{|c|c|c|c|c|c|c|}
\hline \multirow[b]{2}{*}{ 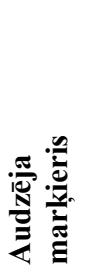 } & \multirow[b]{2}{*}{ 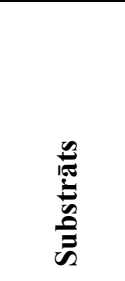 } & \multicolumn{3}{|c|}{$\begin{array}{l}\text { Mediāna } \\
\text { (25. un 75. percentile) }\end{array}$} & \multirow[b]{2}{*}{ 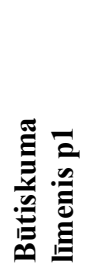 } & \multirow[b]{2}{*}{ 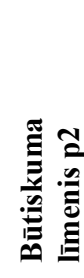 } \\
\hline & & 总 & 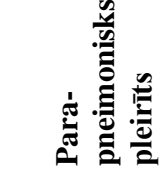 & 空 & & \\
\hline \multirow{3}{*}{ 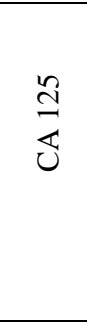 } & $\begin{array}{l}\text { Punktāts } \\
\mathrm{U} / \mathrm{ml}\end{array}$ & $\begin{array}{c}686 \\
(379- \\
1029) \\
\end{array}$ & $\begin{array}{c}412 \\
(245-695)\end{array}$ & $\begin{array}{c}1644 \\
(813-2982)\end{array}$ & 0,001 & 0,002 \\
\hline & $\begin{array}{l}\text { Serums, } \\
\mathrm{U} / \mathrm{ml}\end{array}$ & $\begin{array}{c}182.0 \\
(89-316)\end{array}$ & $\begin{array}{c}62 \\
(41-164)\end{array}$ & $\begin{array}{c}267 \\
(107-597)\end{array}$ & 0,013 & 0,010 \\
\hline & $\begin{array}{l}\text { Punktāts } \\
\text { /serums }\end{array}$ & $\begin{array}{c}3,64 \\
(2,45- \\
5,75)\end{array}$ & $\begin{array}{c}5,5 \\
(3,0-11,0)\end{array}$ & $\begin{array}{c}5,53 \\
(3,82- \\
10,61) \\
\end{array}$ & 0,001 & 0,216 \\
\hline \multirow{3}{*}{ 夰 } & $\begin{array}{l}\text { Punktāts } \\
\mathrm{ng} / \mathrm{ml}\end{array}$ & $\begin{array}{c}0,75(0,51- \\
1,60)\end{array}$ & $\begin{array}{c}1.91 \\
(1,09-3,63)\end{array}$ & $\begin{array}{c}6,23 \\
(0,92-57,3)\end{array}$ & 0,005 & 0,020 \\
\hline & $\begin{array}{l}\text { Serums, } \\
\mathrm{ng} / \mathrm{ml}\end{array}$ & $\begin{array}{c}2,34 \\
(1,40- \\
3,67) \\
\end{array}$ & $\begin{array}{c}2,57 \\
(1,40-4,48)\end{array}$ & $\begin{array}{c}3,07 \\
(1,30- \\
12,79)\end{array}$ & 0,218 & 0,284 \\
\hline & $\begin{array}{l}\text { Punktāts } \\
\text { /serums }\end{array}$ & $\begin{array}{c}0,38 \\
(0,26- \\
0,66)\end{array}$ & $\begin{array}{c}0,70 \\
(0,37-1,48)\end{array}$ & $\begin{array}{c}1,23 \\
(0,65-4,78)\end{array}$ & 0,061 & 0,116 \\
\hline
\end{tabular}

p1 - statistiskā ticamība transudāts vs MPE

p2 - statistiskā ticamība parapneimonisks pleirīts vs MPE

Redzams, ka CA 125 vērtības MPE pacientiem gan pleiras punktātā, gan serumā statistiski ticami atšķiras no transudāta un parapneimoniska pleirīta pacientiem, bet punktāta/seruma attiecība statistiski ticami atšķir MPE no transudāta. Savukārt CEA vērtības statististiski ticami starp MPE, transudāta un parapneimoniska pleirīta grupām atšķiras tikai pleiras punktātā. Kardiāla hidrotoraksa CA 125 līmenis būtiski neatšķīrās no līmeņa parapneimonisko pleirītu grupā ne punktātā $(p=0,850)$, ne arī serumā $(p=0,694)$. 
Lai spriestu par audzēju marḳieru klīnisko nozīmi, tika aprēḳināta jutība un specifiskums gan marḳieru līmeņiem serumā un punktātā, gan arī to punktāta/seruma attiecībai. 2.2. tabulā redzams, ka gandrīz visos gadījumos visaugstākais specifiskums ir ar robežvērtību 75. percentilē, bet jutība -25 . percentilē.

2.2. tabula

\section{CA 125 un CEA jutība un specifiskums dažādām robežvērtībām MPE}

\begin{tabular}{|c|c|c|c|c|}
\hline $\begin{array}{l}\text { Audzēja } \\
\text { marķieris }\end{array}$ & Substrāts & Robežvērtība* & Jutība (\%) & $\begin{array}{l}\text { Specifiskums } \\
(\%)\end{array}$ \\
\hline \multirow{9}{*}{ CA 125} & \multirow{3}{*}{ Punktāts U/ml } & $\geq 813$ & 79,1 & 70,1 \\
\hline & & $\geq 1644$ & 53,7 & 96,1 \\
\hline & & $\geq 2982$ & 28,4 & 98,7 \\
\hline & \multirow{3}{*}{ Serums U/ml } & $\geq 108$ & 76,2 & 69,3 \\
\hline & & $\geq 268$ & 50,8 & 77,9 \\
\hline & & $\geq 597$ & 25,4 & 98,7 \\
\hline & \multirow{3}{*}{ Punktāts/serums } & $\geq 3,82$ & 76,1 & 49,4 \\
\hline & & $\geq 5,53$ & 50,8 & 66,2 \\
\hline & & $\geq 10,61$ & 25,4 & 87,0 \\
\hline \multirow{9}{*}{ CEA } & \multirow{3}{*}{ Punktāts ng/ml } & $\geq 0,92$ & 76,1 & 44,1 \\
\hline & & $\geq 6,23$ & 50,7 & 94,8 \\
\hline & & $\geq 57,3$ & 25,4 & 98,7 \\
\hline & \multirow{3}{*}{ Serums ng/ml } & $\geq 1.30$ & 76,1 & 18,2 \\
\hline & & $\geq 3,07$ & 50,8 & 66,2 \\
\hline & & $\geq 12,8$ & 25,4 & 96,1 \\
\hline & \multirow{3}{*}{ Punktāts/serums } & $\geq 0.60$ & 82,0 & 61,0 \\
\hline & & $\geq 1,23$ & 50,6 & 81,8 \\
\hline & & $\geq 4,78$ & 25,4 & 97,4 \\
\hline
\end{tabular}

*Mediāna, 25. un 75. percentiles

ROC līknes analīze parādīja, ka zemlīknes laukums (area under the curve) visaugstākais ir CA 125 līmenim pleiras punktātā -0,751;0,706 - serumā 
un 0,606 attiecībai punktātā/serumā, kas norāda uz CA 125 visaugstāko diagnostisko jutību punktātā - skat. 2.6. attēlu un 2.3. tabulu.

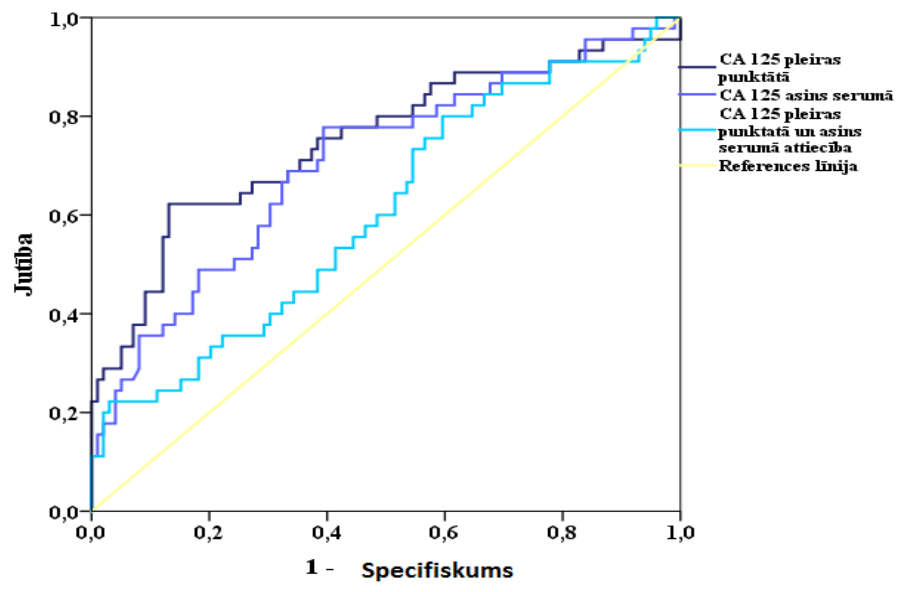

2.6. att. CA 125 ROC līkne un zemlīknes laukums (Area under the curve)

2.3. tabula

Zemlīknes laukuma (Area under the curve) aprēḳins audzēja marḳierim

CA 125

\begin{tabular}{|c|c|c|c|c|c|}
\hline Rādītājs & \multirow{2}{*}{$\begin{array}{c}\text { Zemlīknes } \\
\text { laukums }\end{array}$} & SE & \multirow{2}{*}{$\begin{array}{c}\text { Būtiskuma } \\
\text { līmenis }\end{array}$} & \multicolumn{2}{|c|}{$\mathbf{9 5 \%}$ TI } \\
\cline { 5 - 6 } & & & Apakšējā & Augš̄ejā \\
\hline $\begin{array}{c}\text { CA 125 pleiras } \\
\text { punktātā }\end{array}$ & 0,751 & 0,048 & $<0,001$ & 0,658 & 0,844 \\
\hline CA 125 serumā & 0,706 & 0,048 & $<0,001$ & 0,612 & 0,801 \\
\hline $\begin{array}{c}\text { CA 125 } \\
\text { punktāts/serums }\end{array}$ & 0,606 & 0,051 & $=0,041$ & 0,506 & 0,707 \\
\hline
\end{tabular}

SE - standartkḷūda; 95\% T.I. - ticamības intervāls 95\% robežās

Audzēja marḳiera CEA ROC līknes analīze parādīja, ka zemlīknes laukums markiera līmenim pleiras punktātā ir 0,720 , serumā $-0,575$ un attiecībai 
punktātā/serumā - 0,715, kas arī norāda uz CEA visaugstāko diagnostisko jutību punktātā, bet, atšķirībā no CA 125, arī šì marķiera attiecība punktātā/serumā ir diagnostiski jutīgs tests, savukārt CEA līmenis serumā nav statistiski ticami jutīgs diagnostisks tests - skat. 2.7. attēlu un 2.4. tabulu.

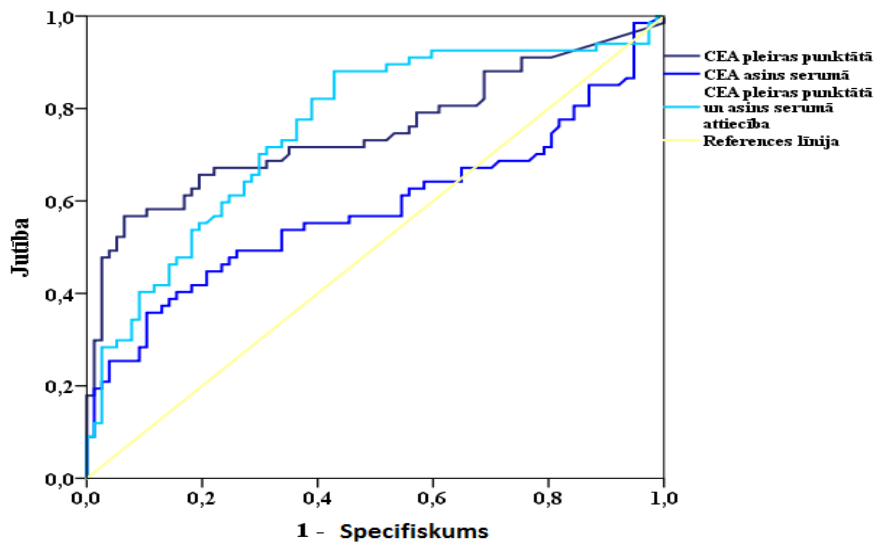

2.7. att. CEA ROC līkne un zemlīknes laukums (Area under the curve)

2.4. tabula

Zemlīknes laukuma (Area under the curve) aprēḳins audzēja marḳierim CEA

\begin{tabular}{|c|c|c|c|c|c|}
\hline Rādītājs & Zemlīknes & \multirow{2}{*}{ SE } & Būtiskuma & \multicolumn{2}{|c|}{ 95\% TI } \\
\cline { 5 - 6 } & laukums & & līmenis & Apakšèjāā & Augšējā \\
\hline $\begin{array}{c}\text { CEA pleiras } \\
\text { punktātā }\end{array}$ & 0,720 & 0,050 & $<0,001$ & 0,621 & 0,819 \\
\hline CEA serumā & 0,575 & 0,056 & $=0,152$ & 0,465 & 0,684 \\
\hline $\begin{array}{c}\text { CEA } \\
\text { punktāts/serums }\end{array}$ & 0,715 & 0,49 & $<0,001$ & 0,618 & 0,811 \\
\hline
\end{tabular}

SE - standartkḷūda; $95 \%$ T.I. - ticamības intervāls 95\% robežās

Ne CEA līmenis pleiras punktātā, serumā un pleiras / punktāta attiecība, nedz arī CA 125 līmenis pleiras punktātā, serumā un pleiras punktāta / seruma 
attiecība statistiski ticami neatšķīāās MPE ar pozitīvu un negatīvu citoloǵiju visos gadījumos $\mathrm{p}>0,05$.

Apvienojot abu marķieru labākos rādītājus ar augstāko jutību un specifiskumu (CA $125 \geq 813 \mathrm{U} / \mathrm{ml}$ un CEA punktāta/seruma attiecība $\geq 0,6$, ieguvām juību 56,4\% un specifiskumu 93,3\%.

\subsubsection{BNP}

Kā papildus marḳieris kardiālu hidrotoraksu diferencēšanai no MPE, tika analizēts BNP serumā un pleiras doumā. BNP mediānās vērtības un 25. un 27. percentile serumā un pleiras punktātā redzamas 2.5. tabulā. BNP līmenis statistiski ticami atšķir transudātu no MPE un parapneimoniska pleirīta, bet nediferencē parapneimonisku pleirītu un MPE savā starpā.

2.5. tabula

BNP mediānās vērtības pleiras punktātā un serumā pacientiem ar transudātu, parapneimonisku pleirītu un MPE

\begin{tabular}{|c|c|c|c|c|c|c|c|}
\hline \multirow[b]{2}{*}{ 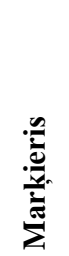 } & \multirow[b]{2}{*}{ 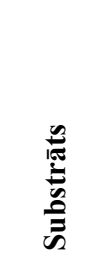 } & \multicolumn{3}{|c|}{$\begin{array}{c}\text { Mediāna } \\
\text { (25. un 27. pecentile) }\end{array}$} & \multirow[b]{2}{*}{ 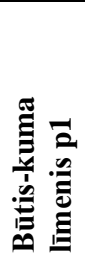 } & \multirow[b]{2}{*}{ 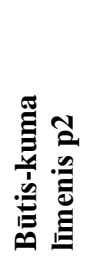 } & \multirow[b]{2}{*}{ 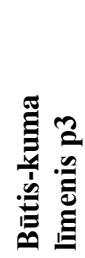 } \\
\hline & & 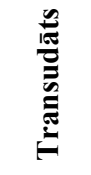 & 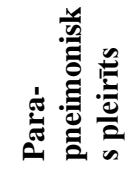 & 空 & & & \\
\hline BNP & $\begin{array}{c}\text { Pleiras } \\
\text { punktāt } \\
\text { s }\end{array}$ & $\begin{array}{l}1097 \\
(494- \\
1582) \\
\end{array}$ & $\begin{array}{c}129 \\
(53-295)\end{array}$ & $\begin{array}{c}97 \\
(61-159)\end{array}$ & 0,010 & 0,504 & 0,006 \\
\hline $\mathrm{g} / \mathrm{ml}$ & Serums & $\begin{array}{c}1631 \\
(071- \\
3386)\end{array}$ & $\begin{array}{c}124 \\
(59-289)\end{array}$ & $\begin{array}{c}109 \\
(46-170)\end{array}$ & 0,001 & 0,932 & 0,001 \\
\hline
\end{tabular}

p1 - statistiskā ticamība transudāts vs MPE

p2 - statistiskā ticamība parapneimonisks pleirīts vs MPE

p3 - statistiskā ticamība parapneimonisks pleirīts vs transudāts

BNP ROC līknes analīze parādīja, ka zemlīknes laukums (area under the curve) ir vienādi gan pleiras punktātā, gan serumā - attiecīgi 0,92 un 0,92, kas 
norāda metodes vienādo un pietiekami augsto diagnostisko vērtību neatkarīgi no tā, kādā vidē BNP tiek noteikts - skat. 2.8. attēlu un 2.6. tabulu.

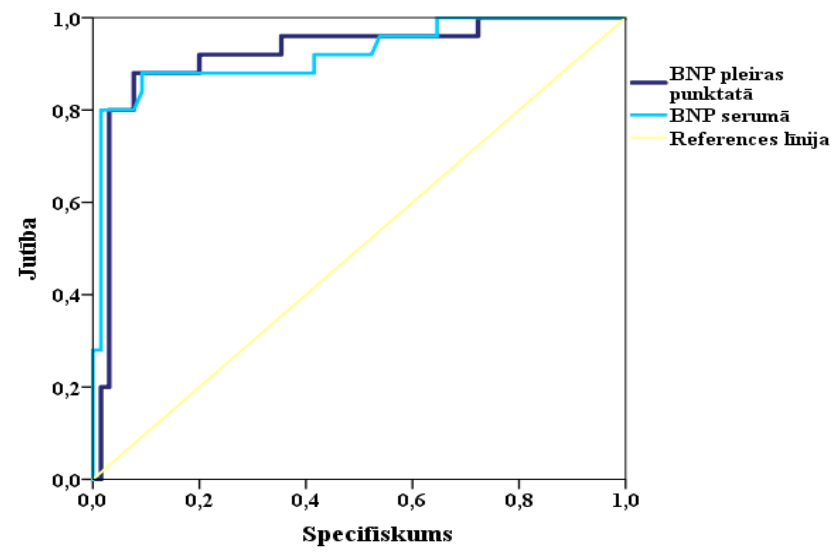

2.8. att. BNP ROC līkne zemlīknes laukums (Area ander the curve)

2.6. tabula

BNP zemlīknes laukuma (area ander the curve) aprēḳins

\begin{tabular}{|c|c|c|c|c|c|}
\hline \multirow{2}{*}{ Rādītājs } & \multirow{2}{*}{$\begin{array}{c}\text { Zemlīknes } \\
\text { laukums }\end{array}$} & \multirow{2}{*}{ SE } & \multirow{2}{*}{$\begin{array}{c}\text { Būtiskuma } \\
\text { limenis }\end{array}$} & \multicolumn{2}{|c|}{ 95\% TI } \\
\cline { 5 - 6 } & & & Apakšèjā & Augšèjā \\
\hline $\begin{array}{c}\text { BNP pleiras } \\
\text { punktātā }\end{array}$ & 0,921 & 0,036 & $<0,001$ & 0,851 & 0,991 \\
\hline BNPserumā & 0,921 & 0,037 & $<0,001$ & 0,849 & 0,993 \\
\hline
\end{tabular}

SE - standartkḷūda; 95\% T.I. - ticamības intervāls 95\% robežās

Lai spriestu par audzēju marḳieru klīnisko nozīmi, tika aprēḳināta jutība un specifiskums gan marķieru līmeņiem serumā un punktātā, gan arī to punktāta/seruma attiecībai (2.7. tabula). Pēc tabulas redzams, ka visaugstākā jutība ir pie viszemākām robežvērtībām gan punktātā, gan serumā. Ja punktāta $\mathrm{BNP} \geq 494 \mathrm{pg} / \mathrm{ml}$, tad jutība ir $76,9 \%$, bet specifiskums $-96,8 \%$; bet ja seruma $\mathrm{BNP} \geq 971 \mathrm{pg} / \mathrm{ml}$, jutība ir 73,1\%, bet specifiskums - 95,9. 
BNP jutība un specifiskums transudātos

\begin{tabular}{|c|c|c|c|c|}
\hline Marķieris & Substrāts & Robežvērtība & $\begin{array}{c}\text { Jutība } \\
(\%)\end{array}$ & $\begin{array}{c}\text { Specifiskums } \\
(\%)\end{array}$ \\
\hline \multirow{6}{*}{$\begin{array}{c}\text { BNP } \\
(\mathrm{pg} / \mathrm{ml})\end{array}$} & \multirow{3}{*}{ Punktāts } & $\geq 494$ & 76,9 & 96,8 \\
\hline & & $\geq 1097$ & 50,0 & 97,3 \\
\hline & & $\geq 1582$ & 24,0 & 97,3 \\
\hline & \multirow{3}{*}{ Serums } & $\geq 971$ & 73,1 & 95,9 \\
\hline & & $\geq 1631$ & 50,0 & 95,9 \\
\hline & & $\geq 3386$ & 23,1 & 97,3 \\
\hline
\end{tabular}

\subsubsection{PAI-1}

PAI-1 līmeṇa mediāna pleiras punktātā (ng/ml): transudātu grupai 135 (20-236); malignu eksudātu grupai 188 (73-287); parapneimonisku pleirītu grupai 291 (213-499). PAI-1 līmeņa atšķirība starp parapneimonisku pleirītu un malignu pleiras eksudātu bija statistiski ticama $-\mathrm{p}<0,001$, bet starp transudāta un malignu eksudāta PAI 1 vērtībām nav statistiski ticamas atšķirības - $\mathrm{p}=0,07$. Arī transudāts un parapneimonisks eksudāts savā starpā atšḳ̄īās statistiski ticami $(\mathrm{p}<0,001)-2.9$. attēls. 


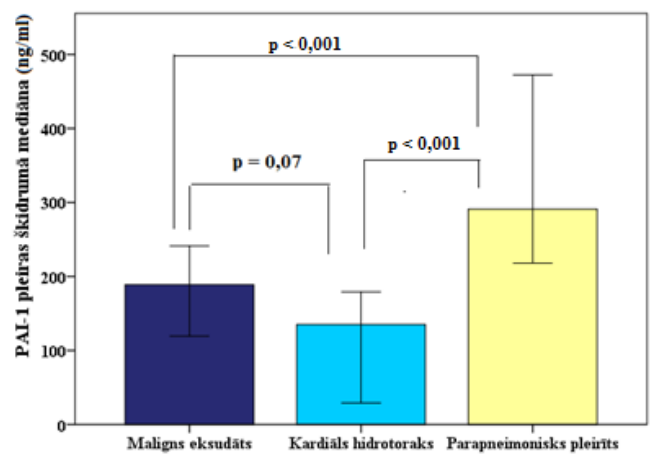

2.9. att. PAI-1 līmenis pleiras šḳidrumā

PAI-1 līmenis (ng/ml) serumā pacientiem ar MPE bija 144 (77-207), pacientiem ar kardiālu hidrotoraksu - 69 (34-166), bet parapneimonisku pleirītu grupā - 204 (151-412). Arī serumā statistiski ticama bija atšḳirība starp parapneimoniska pleirīta un MPE grupām $(\mathrm{p}=0,003)$ un parapneimoniska pleirīta un kardiāla hirotoraksa grupām $-<0,001$, bet MPE un transudāta grupas savā starpā statistiski ticami neatškīiāa $-\mathrm{p}=0,052)-2.10$. attēls.

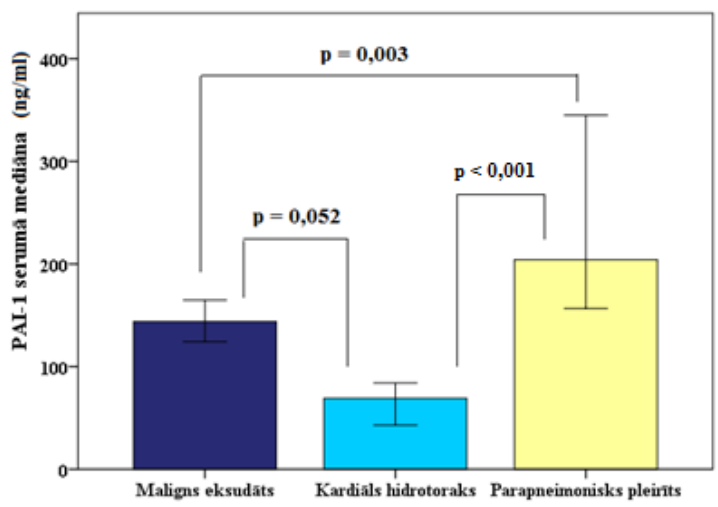

2.10. att. PAI-1 līmenis serumā 


\section{DISKUSIJA}

Mūsu veiktajā pētījumā galvenais mērḳis bija noskaidrot, vai iespējams izmantot papildus bioḳīmiskos marķierus, lai diagnosticētu MPE situācijāa kad MPE izmeklēšanas zelta standarts - videoasistēta torakoskopija nav pieejama kā tas ir vairumā Latvijas slimnīcu. Lai saprastu, cik aktuāla ir MPE problēma slimnīcā un kā tie tiek diagnosticēti, vispirms veicām retrospektīvu datu analīzi par to, kā pacienti ar şķidrumu pleiras dobumā tiek izmeklēti, kādas diagnozes šiem pacientiem tiek noteiktas, cik procenti no tiem ir MPE un kādā veidā tie tiek pierādīti. Pēc tam, prospektīvi analizējot pacientus ar šķidrumu pleiras dobumā, kuri tika stacionēti 2. Pulmonolog̣ijas nodaḷāa, izvērtējām papildus bioḳīmisko marķieru (CA 125, CEA, PAI-1 un BNP) diagnostisko nozīmi MPE diferenciāldiagnostikā. Konstatējām, ka retrospektīvi analizētajā periodā analizētajā periodā trūkst konsekvences izmeklēšanas metožu izvēlē, kaut gan medicīnas literatūrā nepieciešamās izmeklēšanas metodes un algoritmi ir labi definēti un aprakstīti. Konstatējām faktu, ka 4,6 \% no visiem gada laikā ārstētiem pacientiem ir bijis šķidrums pleiras dobumā, kā arī to, ka pacientiem ar šķidrumu pleiras dobumā mirstîba ir 3 reizes augstāka nekā pacientiem bez škiidruma pleiras dobumā. Visbiežākais cēlonis škidrumam pleiras dobumā ir kardiāls hidrotorakss un to ticami var diferencēt, nosakot BNP līmeni asinīs. MPE diagnostikā kā papildus marḳieris vislabāk var kalpot CA 125 pleiras punktātā, bet PAI-1 līmenis, iespējams, norāda uz aktivizētiem fibrinolīzes procesiem MPE salīdzinot ar parapneimoniskiem pleirītiem.

\subsection{Pleiras šḳidruma epidemioloǵija un etioloǵija}

Pētījumā tika konstatēts, ka no visiem slimnīcas "Gaiļezers" terapeitiska profila nodaḷās ārstētajiem pacientiem 4,6\% ir šķidrums pleiras dobumā. Pēc pētījumā iegūtajiem datiem redzams, ka pleiras šķidrums visbiežāk konstatējams 
cilvēkiem pēc 40 gadu vecuma - 95,8\% no saslimušajiem ir vecāki par 41 gadu, jādomā, tāpēc, ka, pieaugot vecumam, pieaug arī risks saslimt ar sirds asinsvadu un ḷaundabīgām slimībām, kas ir visbiežākie pleiras šķidruma iemesli.

N̦emot vērā to, ka šḳidrums pleiras dobumā parasti ir kādas citas slimības komplikācija, incidences un prevalences aprēḳināšana ir ḷoti grūts uzdevums un ir l̦oti maz pētījumu, kuros mēgeināts apkopot šāda veida epidemioloǵiskos datus. Viens no vislabāk organizētajiem pleiras šķidruma epidemioloǵiskajiem pētîjumiem ir Miloslav Marel 1988. gadā Bohēmijā veiktais pētījums (Marel et al., 1993). Pētījuma mērḳis bija atklāt pacientus ar šķidrumu pleiras dobumā gan dzīves laikā, gan pēc nāves un konstatēt pleiras šķidruma incidenci un etiologiju. Pētījuma pacienti tika atlasīti pēc konkrētiem kritērijiem stingri noteiktā reǵionā. Kopā viena gada laikā 142 pacientiem (gan dzīviem, gan mirušiem) tika konstatēts šḳidrums pleiras dobumā. 45,8\% no visiem pacientiem tas bija kardiālas ǵenēzes, $21,8 \%$ no visiem pacientiem bija MPE, $17 \%$ no visiem pacientiem bija parapneimonisks pleirīts, 5,6\% no visiem pacientiem škidrums pleiras dobumā bija plaušu artērijas trombembolijas dēl, 4,2\% no visiem pacientiem bija hemotorakss. Tika aprēķināta incidence - 32 pleiras šķidruma gadījumi uz 100000 iedzīvotāju.

Mūsu pētījumā retrospektīvi tika izanalizētas 716 stacionāra medicīniskās kartes ar izrakstīšanās diagnozē minētu pleiras šķidrumu, bet nebija iespējams precīzi definēt apgabalu, no kura šie pacienti stacionēti, tāpēc incidenci aprēķināt šin̄̄ pêtījumā nevar, tomēr kopumā mūsu iegūtie dati ir salīdzināmi ar Marel iegūtajiem datiem. Visbiežākais cēlonis šķidrumam pleiras dobumā bija sirds mazspēja - pēc izrakstīšanās diagnozes, kardiāls hidrotorakss bija 426 (59,5\%) pacientiem. Otrais biežākais cēlonis tāpat kā Marel pētījumā bija MPE 103 $(14,4 \%)$ pacientu, bet trešais cēlonis - parapneimonisks pleirīts - $71(9,9 \%)$ pacientam un pleiras empiēma - $30(4,2 \%)$ pacientu. 
Kolēg̊i Kauṇā (Zablockis et al., 2002) gadā analizēja 220 pleiras šķidruma gadījumus. Transudāti tika konstatēti 24\% gadījumu, bet eksudāti - 76\% gadījumu. Kardiāli hidrotoraksi konstatēti $14,5 \%$, nefrotisks sindroms $-5,5 \%$ gadījumu, aknu cirozes izraisīts transudāts $-2,5 \%$ gadījumu, parapneimonisks pleirīts - 13\%, pleiras empiēma - 9\%, tuberkuloze - 6\%, bet MPE 16,5\% gadījumu. 5,5\% gadījumu konstatēja PATE ar eksudātu pleiras dobumā (Zablockis et al., 2002). Mūsu gadījumā retrospektīvajā pētījumā kardiālu hidrotoraksu bija ievērojami vairāk - 59,5\%, kas izskaidrojams ar to, ka pētījumā tika iekḷautas arī kardioloǵijas nodą̧as, savukārt prospektīvajā pētījuma dạ̣ā, kurā tika analizēti tikai Pulmonologijas nodaḷas pacienti, kardiāli hidrotoraksi līdzīgi kā Kauņas kolēǵu pētījumā bija 29,2\%. Retrospektīvā pētījumā MPE bija 14,4\% pacientu līdzīgi kā Kauņas kolēgiem, bet prospektīvi analizēto pacientu vidū MPE bija ievērojami vairāk - 46\%, kas arī izskaidrojams ar specializētu stacionēšanas nodaḷu. Parapneimonisks pleirīts un pleiras empiēma bija līdzīgā skaitā gadījumu - retrospektīvā pētījumā attiecīgi 9,9 un 4,2\%. Savukārt tuberkulozs pleirīts retrospektīvi analizētajos datos bija tikai $0,8 \%$ gadījumu, bet prospektīvi analizētajā pacientu grupā - 3,5\% gadījumu, kas arī izskaidrojams ar stacionēšanu specializētā nodạ̦ā. PATE izraisīts pleiras eksudāts retrospektīvi analizētajā grupā bija tikai $1 \%$ gadījumu, bet prospektīvajā pētījumā - tikai 1 pacientam. N̦emot vērā iepriekš aprakstīto pētījumu datus, kuros PATE pleirīit konstatēti ap 5\% gadījumu, kā arī Broaddus (2016) aprēḳinus par PATE pleirītu biežumu, var apgalvot, ka PATE RAKUS “Gaiḷezers” analizētajā periodā varētu būt diagnosticēta pārāk reti.

Valdes ar kolēgiem 1996. gadā veica prospektīvu pêtījumu noteikta reǵiona stacionāros Spānijā. 5 gadu laikā viṇi atklāja 642 pacientus ar šķidrumu pleiras dobumā ar vidējo vecumu 57 gadi, 401 no tiem bija vīrieši. Šinī reǵionā visbiežākais pleiras eksudāta cēlonis bija tuberkuloze (25\%), malignitāte $(22,9 \%)$ un hroniska sirds mazspēja $(17,9 \%)$. Malignitātes grupā visbiežākais 
MPE cēlonis bija plaušas audzējs - 32\% gadījumu, krūts audzējs - 11,5\% gadījumu, limfoma - 10,8\% gadījumu un olnīcu audzējs - 7,5\% gadījumu. 14,3\% gadījumu primāro audzēju nevarēja identificēt. $69,4 \%$ no tuberkuloza pleirīta pacientiem sastādīja pacienti, kas bija jaunāki par 40 gadiem, bet MPE pacienti 83\% gadījumu bija vecāki par 50 gadiem (Valdes et al., 1996). Mūsu valstī tuberkulozes izplatība ir ievērojami augstāka nekā Spānijā - Latvijā jaunu un jau ārstētu tuberkulozes gadījumu skaits uz 100000 iedzīvotāju 2010. gadā bija 2050, bet Spānijā - 10-19 (Dara et al., 2013), tomēr tuberkulozu pleirītu mūsu apstrādātajos datos ir daudz mazāk, kas skaidrojams ar specializētu tuberkulozes diagnostikas un ārstēšanas slimnīcu esamību Latvijā. Novērojamas arī būtiskas pacientu vecuma atškirīibas - retrospektīvi analizētajā pacientu izlasē jaunāki par 41 gadu bija tikai 4,2\% pacientu, bet modālais pacientu vecums bija 71-80 gadi, ko var izskaidrot ar to, ka tuberkulozs pleirīts galvenokārt sastopams jauniem cilvēkiem, savukārt sirds mazspēja un ļaundabīgas slimības - vecākiem. Prospektīvi analizētajā grupā MPE sadalījums pa primāro audzēju grupām bija līdzīgs - 37\% gadījumu tas bija plaušu vēzis, 20\% - krūts vēzis un 20\% olnīcu vēzis. Pacienti ar MPE limfomas dēḷ netika novēroti, jādomā, tādēḷ, ka pacienti ar hematolog̣iskām slimībām Latvijā galvenokārt tiek stacionēti specializētā nodāḷā.

Pētījumā ar 1000 pacientiem, kuriem tika veikta pleiras dobuma punkcija, Villena Garrido ar līdzstrādniekiem 36\% gadījumu (364 pacientiem) konstatēja MPE (Villena Garrido et al., 2002). Mūsu retrospektīvajā pētījumā no 272 pacientiem, kuriem bija veikta pleiras punkcija, tikai 14,7\% konstatēja MPE, kas ir ievērojami mazāk, bet prospektīvajā pētījumā specializētajā nodaḷā MPE bija 46,5\%, kas, iespējams, varētu liecināt par MPE hipodiagnostiku stacionārā kopumā un labāku MPE diagnostiku specializētā nodaḷā.

Čehijā tika veikts pētījums, kurā tika iekḷauti pacienti, kuri 4 gadu laikā bija stacionēti plaušu slimību profila slimnīcā Prāgā. 44,6\% gadījumu bija 
konstatēts MPE pleiras dobumā, 11,7\% bija parapneimonisks šķidrums, 6,4\% empiēma, 6,4\% tuberkulozs pleirīts (Loddenkemper et al., 2002), kas ir salīdzināms ar mūsu prospektīvā pētījuma datiem Pulmonoloǵijas nodaḷā, kur MPE konstatēja 46,5\% pacientu un 18,8\% - parapneimonisku pleirītu un 3,5\% pacientu - tuberkulozu pleirītu.

Svarīgi atzīmēt, ka kopējā letalitāte stacionāra "Gaiḷezers" terapeitiskā profila nodạ̦ās gada laikā bija 4,4\%, bet pacientiem, kuriem izrakstīšanās diagnozē minēts šķidrums pleiras dobumā, letalitāte bija vairāk kā trīs reizes augstāka $-14,1 \%$, kas statistiski ticami $(\mathrm{p}<0,001)$ norāda uz pleiras patologijas pacientu ievērojami augstāko risku. Šāda veida dati šobrīd pasaules literatūrā nav atrodami.

\subsection{Pleiras šḳidruma diagnostikas metodes}

Mēs retrospektīvi analizējām izmeklējumus, kādi veikti pacientiem ar škidrumu pleiras dobumā. Tika konstatēts, ka visbiežāk veiktais izmeklējums ir krūšu kurvja rtg - 90,9\%, bet pleiras dobuma ultrasonoskopija vēsturēs tika dokumentēta tikai 19,7\% no visiem gadījumiem. Savukārt 5,9\% pacientu netika veikta ne krūšu kurvja rentgenogrāfija, nedz arī datortomogrāfija.

Teorētiski visiem pacientiem, kuriem pirmo reizi mūžā konstatēts šḳidrums pleiras dobumā un kuriem klīniski nav pārliecinošu datu par transudātu (sirds vai aknu mazspējas dekompensācija vai zināma nieru slimība), būtu jāveic pleiras dobuma punkcija (Havelock et al., 2010, Villena Garrido et al., 2014). Pēc mūsu pêtījumā analizētās medicīniskās dokumentācijas datiem, no 716 pacientiem punkcija tika veikta $272(38 \%)$. 74\% pacientu no tiem, kuriem nebija veikta punkcija, izrakstīšanās diagnozē tika minēts kardiāls hidrotorakss, bet 116 pacientiem (26\%) pleiras šķidrums netika saistīts ar kardiālu patologiju, tomēr punkcija veikta netika. Jāatzīmē arī, ka tikai $22,8 \%$ mirušo pacientu tika veikta pleiras dobuma punkcija, kas, jādomā, tomēr liecina par pārāk konservatīvu 
taktiku. Izvērtējot rezultātus, konstatēts, ka visbiežāk (60,2\%) punktēti pacienti ar malignas dabas eksudātu izrakstīšanās diagnozēe, bet visretāk kardiālas hidrotoraksi - (23\%). Tendence atzīstama par pareizu, tomēr nepunktēto pacientu skaits liek domāt par nepietiekamu klīnisko datu, t.sk., pleiras punktāta bioḳīmiskā sastāva analīzi un līdz ar to par iespējamām diagnostiskām kḷūdām.

Gadījumos, kad ir indikācijas punktēt pleiras dobumu, tas būtu jādara pēc iespējas ātrāk vai neatliekami tad, ja pacientam ir elpošanas nepietiekamība vai aizdomas par pleiras empiēmu, bet pārējos gadījumos punkcija veicama laikā, kad pieejams apmācīts speciālists (Havelock et al, 2010).. Šī brīža nostādne paredz, ka pleiras dobuma punkcija jāizdara pieredzējušam speciālistam atbilstošos apstākḷos (ultrasonoskopijas iespējas, komplikāciju novēršanas iespējas), tātad parasti darba dienas laikā. Invazīvām procedūrām, kuras bez stingrām indikācijām tiek veiktas pēc pusnakts, parasti ir vairāk komplikāciju (Havelock et al., 2010; Feller-Kopman et al., 2018), tomēr ilga vilcināšanās, it sevišķi, parapneimonisku pleirītu gadījumos nav ieteicama, ņemot vērā faktu, ka parapneimonisks pleirīts var komplicēties ar fibrīna septām un pleiras empiēmu pat 12 stundu laikā (Villena Garrido et al., 2014, Davies et al, 2010). Mūsu veiktajā pētījumā pēc retrospektīvi analizeto datu analīzes tikai 71 pacientam (26,1\% no punktētajiem pacientiem) pleiras punkcija veikta pirmajā dienā, 53 (19,5\% no punktētajiem pacientiem) - otrajā dienā pēc iestāšanās, pārējiem pacientiem pleiras dobuma punkcija tika veikta vēlāk, arī 14.-30. dienā pēc iestāšanās, kas varētu liecināt par novēlotiem diagnostiskiem un ārstnieciskiem pasākumiem un nepietiekami agresīvu taktiku, kas noved pie ilgāka laika, ko pacients pavada slimnīcā, iespējamām komplikācijām un izmaksu pieauguma.

Pēdējās desmitgadēs arvien vairāk tiek uzsvērts, ka pleiras dobuma punkcijai nepieciešama ultrasonoskopijas kontrole - vai nu pirms punkcijas vai arī punkcijas laikā, turklāt iepriekšēja punkcijas vietas atzīmēšana citā telpā vai nodą̧ā netiek rekomendēta. Visaugstākais komplikāciju risks ir ārstam, kurš nav 
trenēts punkciju veikšanā un kurš neizmanto ultrasonsokopijas metodi - 15\% gadījumu attīstās pneimotorakss, $4,7 \%$ nepieciešama pleiras dobuma drenāža un 12,9\% gadījumu punkcijas laikā neizdodas iegūt šķidrumu (Havelock et al., 2010, Feller-Kopman et al., 2018). Salīdzinājumam trenētam ārstam, kurš izmanto ultrasonoskopiju, attiecīgie riski ir 3,6\%; $0,9 \%$ un 2,7\%. Mūsu retrospektīvjā analīzē no 272 veiktajām punkcijām tikai 104 gadījumos tika veikta ultrasonoskopija. Pavisam ultrasonoskopija tika veikta 141 pacientam $(19,7 \%)$, kas norāda uz nepietiekamu ultrasonoskopijas metodes izmantošanu analizētajā periodā. Dati par pleiras dobuma punkcijas komplikācijām mūsu pētījumā netika apkopoti.

Šādi dati, mūsuprāt, liecina par izmeklēšanas algoritma neesamību izvērtētajā periodā stacionārā "Gailiezers".

Literatūrā publikācijas par šādā veidā analizētajiem datiem netika atrastas, iespējams, tāpēc, ka, pat ja šādi dati tiek analizēti, tie vairāk kalpo slimnīcas iekšējās kvalitātes kontroles sistēmai. Arī mūsu uzdevums, retrospektīvi analizējot pacientu vēstures, bija konstatēt esošo stāvokli slimnīcā un saprast, kādā veidā to var uzlabot.

\section{Pleiras šḳidruma laboratorās izmeklēšanas metodes}

\subsubsection{Bioḳīmiskās izmeklēšanas metodes}

Izvērtējot, kādam būtu jābūt pleiras punktāta izmeklējumu minimumam, jāvadās pēc klīniskās ainas. Saskaņā ar Light un citu autoru norādījumiem (Sahn, 2003, Havelock et al., 2010, Broaddus et al., 2016), gadījumos, kad ir augsta transudāta iespējamība, piel̦aujams noteikt tikai LDH un olbaltumvielas pleiras šķidrumā un serumā jeb t.s. Laita kritērijus. Ja olbaltumvielas pleiras punktātā/olbaltumvielas serumā $<0,5 ; \mathrm{LDH}$ pleiras punktātā/LDH serumā $<0,6$ un LDH pleiras punktātā $<2 / 3$ no konkrētās laboratorijas normas augšèjās robežas serumā, tas ir transudāts un nav nepieciešama tālāka izmeklēšana. 
Laita kritēriji šobrīd ir galvenā metode, kuru izmanto transudātu un eksudātu diferencēšanai. Tā kā tālākā taktika transudātu un eksudātu gadījumos ir radikāli atškirīga, tad šo kritēriju nozīmi nevar pārvērtēt. Abās pieejamās vadlīnijās par šḳidrumu pleiras dobumā Laita kritēriji tiek minēti kā obligāti veicami, turklāt, lai Laita kritērijus varētu pilnvērtīgi izvērtēt, olbaltumvielas un LDH jānosaka ne tikai pleiras punktātā, bet arī asinīs (Hooper et al., 2010, Villena Girrargo et al, 2014).

Ja klīniskā aina liecina par iespējamu eksdudātu ( nav sirds, aknu vai nieru mazspējas pazīmes, ir aizdomas par malignitāti, pneimoniju vai plaušu artēriju trombemboliju), papildus jānosaka punktāta klīniskā analīze un pH. Ja pleiras škidruma $\mathrm{pH}<7,3$, bet asiṇu $\mathrm{pH}$ normāls, tad eksudāta gadījumā jādiferencē starp komplicētu parapneimonisku pleirītu vai empiēmu, malignitāti, barības vada ruptūru, reimatoīdu pleirītu, lupus pleirītu un tuberkulozu pleirītu (Sahn, 2003, Havelock et al., 2010, Villena Girrado et al., 2014). Ja pH noteikt nav iespējams tehnisku iemeslu dēl, var vadīties pēc klīniskās ainas vai arī noteikt glikozes līmeni. Ja pleiras virsma ir vesela, tad glikozes līmenis pleiras punktātā ir vienāds ar glikozes līmeni serumā. Zems glikozes līmenis parasti liecina par bakteriālu infekciju, reimatō̄du artrītu vai tuberkulozu pleirītu, malignitāti vai barības vada ruptūru. Glikoze $<1,5 \mathrm{mmol} / 1$ parasti ir pleiras empiēmas un reimatoīdā astrīta gadījumos. Ja glikoze ir $<3,4 \mathrm{mmol} / \mathrm{l}$, tas ir kritērijs pleiras dobuma drenāžas uzsākšanai (Hooper et al., 2010).

Mūsu pētījumā retrospektīvi analizējot datus, tika konstatēts, ka pleiras punktāta analǐžu kombinācijas ir ḷoti dažādas. Visbiežāk - 130 (47\%) gadījumu vienlaicīgi noteiktas klīniskā analīze, LDH, olbaltumvielas un citologiija. Pārējās analīzes un analīžu kombinācijas noteiktas ievērojami retāk. 29 (10,7\%) gadījumos pleiras punktāta analīzes netika veiktas vispār. Nevienā no gadījumiem netika izvērtēta olbaltumvielu līmeņa attiecība pleiras şķidrumā un asinīs un LDH attiecība pleiras šḳidrumā un asin̄̄s, kas apliecina ārstu vājo 
izpratni par transudāta un eksudāta diferenciāldiagnostikas būtiskumu. Svarīgi atzīmēt, ka 98 gadījumos (36\% no punktētajiem pacientiem) nebija noteikts LDH, kas ir svarīgākais parametrs transudāta un eksudāta diferencēšanā (Light, 2013). Tāpat jāatzīmēe, ka nevienam pacientam pleiras šķidrumā netika noteikts pH, kas gan, iespējams, izskaidrojams ar tehniskām grūtībām izmantot gāzu analizatoru. Mūsuprāt, apstākḷlos, kad pH noteikšana gāzu analizatorā ir tehniski sarežǵīta (liels attālums līdz laboratorijai un personāla trūkums, lai pietiekami ātri nogādātu paraugu laboratorijā), tā vietā piln̄̄gi piel̦aujama ar̄̄ glikozes noteikšana pleiras dobuma šķidrumā. Tomēr pēc analizētajiem datiem, tikai vienā gadījumā no 272 bija noteikta glikoze, sešos gadījumos bija noteikta lipāze. Parietālās pleiras biopsija veikta deviṇos $(1,3 \%)$ pacientiem, pieciem no tiem konstatēts tuberkulozs pleirīts. Torakoskopija tika veikta tikai diviem $(0,3 \%)$ pacientiem, kas izskaidrojams ar to, ka analizētajā stacionārā nav torakālās ķirurğijas nodaḷas. Mums pieejamajā literatūrā neizdevās atrast pētījumus, kuros līdz̄̄gā veidā tiktu analizēti stacionārā veiktie pleiras dobuma šķidruma izmeklēšanas veidi, tāpēc grūti spriest, vai stacionārs "Gaiḷezers" būtiski atšķiras no citiem stacionāriem, tomēr ir skaidrs, ka analizētie dati liecina par nepietiekamu klīnisko rekomendāciju ievērošanu praksē.

Prospektīvā pētījumā visiem pacientiem tika noteikti Laita kritēriji. Konstatēts, ka kardiāls hidrotorakss bija 42 pacientiem, 34 (81\%) pacientiem Laita kritēriji atbilda transudātam, bet 8 (19\%) pacientiem Laita kritēriji atbilda eksudātam, kas precīzi atbilst iepriekšminētiem literatūrā (Porcel et al., 2004; Bielsa et al., 2012; Light R.W., 2013) aprakstītajiem secinājumiem. Veicot papildus aprēkinus, šiem pacientiem tika noteikts olbaltumvielu gradients. Septiniem pacientiem tas bija $>31 \mathrm{~g} / \mathrm{L}$, bet vienam pacientam tas bija $<31 \mathrm{~g} / \mathrm{L}$, bet BNP serumā šim pacientam bija 1631 pg/ml. Parapneimoniska pleirìta grupā (29 pacienti) visiem pacientiem bija pozitīvs vismaz viens Laita kritērijs. Parapneimonisko pleirītu grupa visiem pacientiem bija pozitīvs arī trešais Laita 
kritērijs - LDH līmenis punktātā (168-1006 U/L), kas liek domāt, ka parapneimonisku pleirītu gadījumos iespējams izmantot tikai 3. Laita kritēriju, papildus nenosakot LDH un olbatumvielas serumā. MPE grupā (67 pacienti), vismaz viens Laita kritērijs bija pozitīvs 65 (97,1\%) pacientiem, kas atbilst literatūrā aprakstītajiem datiem. Tikai $52(77,6 \%)$ pacientu bija pozitīivs 3. Laita kritērijs, kas norāda uz to, ka neskaidras diagnozes gadījumā, it sevišķi, ja ir aizdomas par MPE, tomēr jāveic LDH un olbaltumviela noteikšana arī asins serumā.

\subsubsection{Citoloğija}

Citolog̣iskā izmeklēšana ir plaši lietota metode MPE diagnostikā, tomēr tikai vidēji $60 \%$ gadījumu pleiras punktātā izdodas atrast malignas šūnas, turklāt paraugu atkārtota pleiras punktāta izmeklēšana nepaaugstina metodes jutību (Hooper et al., 2010). Mūsu pētījumā prospektīvi citologiskā pleiras šḳidruma analīze tika veikta visiem pacientiem, malignas šūnas tika atrastas $44(65,7 \%)$ pacientu, $38(83,4 \%)$ no tiem tās atrada jau pirmajā paraugā, bet $6(13,6 \%)$ - nosūtot izmeklēšanai atkārtotu pleiras dobuma punktātu. Šie rezultāti kopumā atbilst publicētajiem datiem par citologiskās izmeklēšanas jutību.

\subsubsection{Bakterioloğija}

Bakterioloǵiskā izmeklēšana jāveic visos gadījumos, kad iespējams eksudāta infekciozas dabas cēlonis, tomēr jutība kopumā ir zema. Ap 15-20 \% no pleiras punktāta paraugiem uzsējumā tiek identificētas baktērijas (Mohanty et al., 2007; Broaddus et al., 2016). Mūsu gadījumā tikai 2 (7\%) no 27 izmeklētajiem paraugiem uzsējumā identificēja baktērijas (Klebsiella pneumoniae un Staphylococcus saccrolyticus), kas ir mazāk kā aprakstītajos 
literatūras datos. L,oti zemo metodes jutību mūsu gadījumā var skaidrot ar nepietiekami ātru paraugu nogādāšanu mikrobiologijas laboratorijā.

\subsubsection{Audzēju marḳieri}

Ṇemot vērā faktu, ka pleiras punktāta citoloǵiskai izmeklēšnai ir samērā zema jutība, kā arī to, ka līdzīgi kā stacionārā "Gaiḷezers" arī daudzās citās pasaules slimnīcās ne vienmēr ir pieejama torakoskopija MPE vai citas diagnozes apstiprināšanai, tiek pētītas alternatīvas metodes, kas varētu palīdzēt diferencēt MPE no citas etioloǵijas eksudātiem. Audzēju marķieru līmenis pleiras punktātā ir viens no pētījumu virzieniem, kaut gan dažos pēdējos gados tālāki pētījumi šinī jomā vairs netiek rekomendēti (Feller-Kopman et al., 2018).

\section{CEA un CA 125 robežvērtību, zemlīknes laukumu, jutības un specifiskuma salīdzinājums}

Feng un kolēgi analizēja CEA pleiras punktātā 156 pacientiem, 114 no tiem ar MPE, bet 42 ar tuberkulozu pleirītu. Pie robežvērtības 4,5 metodes jutība bija 75\%, bet specifiskums - 96\% (Feng et al., 2016). Xu un kolēǵi noteica CEA līmeni 60 malignos un 58 labdabīgos pleiras šķidrumos, konstatējot, ka 54 pacientiem ar malignu pleiras eksudātu CEA līmenis pleiras punktātā ir lielāka par $5,5 \mathrm{ng} / \mathrm{ml}$ un pie šādas robežvērtības, kombinējot CEA ar tumora marḳieri sRCAS, jutība bija 98,3 un specifiskums - 91,4\%. (Xu et al., 2014), kas liecina par to, ka apvienojot dažādus diagnostiskus marḳierus, jutība paaugstinās. Pēc mūsu datiem pie robežvērtības $6.23 \mathrm{ng} / \mathrm{ml} \mathrm{ng} / \mathrm{ml}$ CEA jutība bija tikai 50,7\% un specifiskums $94,8 \%$, bet apvienojot CA 125 un CEA, to jutība bija 56,4\%, bet specifiskums $-93,3 \%$.

Son un līdzautori analizēja 47 labdabīgus un 52 malignus pleiras eksudātus, salīdzinot audzēja marķieru CD66c, CEA, CA 19-9 un CYFRA 21-1 pleiras punktātā diagnostiskās vērtības, konstatējot, ka pie robežvērtības 2,5 
$\mathrm{ng} / \mathrm{ml}$ visaugstākā diagnostiskā vērtība ir CEA - jutība 87,2 \% un specifiskums 92,3\% (Son SM, 2015). Sharma ar kolēgiem arī analizējis CEA pleiras punktātā. Pētījumā ar 30 plaušu vēža pacientiem ar MPE un 18 tuberkuloza pleirīta pacientiem, seruma CEA jutība pie robežvērtības $4,8 \mathrm{ng} / \mathrm{ml}$ bija $78,3 \%$, bet pleiras punktāta CEA jutība - 82,6\% (Sharma et al., 2015). Pētījumā ar 601 MPE un 595 citas etiologiijas pleiras šķidrumu tika noteikts CEA pleiras punktātā un pie robežvērtības $0,69 \mathrm{ng} / \mathrm{ml}$ jutība bija $69 \%$, bet specifiskums - 82\% (Li et al., 2015). Bunjhoo ar kolēgiem analizēja 28 MPE un 28 malignus pleiras eksudātus un konstatēja, ka CEA jutība punktātā pie robežvērtības 3,48 ng/ml bija 75\%, bet specifiskums - 86\% (Bunjhoo H. et al., 2012). Pēc mūsu datiem pie augstākas robežvērtības $(\geq 6,23)$ jutība bija ievērojami zemāka $(50,7 \%)$, bet specifiskums bija līdzīgs - 94,8\%. Iespējams, ka šīs atškirības skaidrojamas ar to, ka mūsu pētījumā bija mazāks pacientu skaits.

Gan CEA, gan arī CA 125 pleiras punktātā un serumā tika noteikti 95 pacientiem ar MPE un 35 pacientiem ar tuberkulozu pleirītu. CEA vislielākais zemlīknes laukums, jutība un specifiskums bija punktātā pie robežvērtības 3,35 ng/ml (attiecīgi 0,86,75\% un 94\%), arī CA 125 vislabākie rezultāti bija punktātā pie robežvērtības $644 \mathrm{U} / \mathrm{mL}$ - attiecīgi 0,78; $61 \%$ un 83\% (Gu et al., 2016). CEA un CA 125 pleiras punktātā noteica arī Antonangelo ar kolēǵiem 114 MPE un 42 tuberkuloza pleirīta pacientiem. CEA pie robežvērtības $5,2 \mathrm{ng} / \mathrm{ml}$ bija $65 \%$ jutība un $97,5 \%$ specifiskums, bet CA 125 pie robežvērtības 345,65 U/mL - 68\% jutība un $83 \%$ specifiskums (Antonangelo et al., 2015). Līdzīgi mūsu pētījumā punktātā abu marḳieru jutība un specifiskums bija visaugstākie, bet robežvērtība, pie kuras bija visaugstākā jutība un specifiskums (attiecīgi 53,7\% un 96,1\%), bija ievērojami augstāka - 1644 U/ml.

Šajos pētījumos ar dažādu pacientu skaitu galvenokārt tika analizēts CEA punktātā paralēli citiem marķieriem, tikai vienā pētījumā analizēts CA 125 un CEA gan serumā, gan punktātā, kā arī punktāta/seruma attiecība. Visos 
analizētajos pētījumos abu marķieru robežvērtība punktātā labākajai testa jutībai un specifiskumam bija zemāka kā mūsu pētījumā: CEA 2,9-8,0 ng/ml (mūsu rezultātos 6,23 ng/ml), CA 125 mediānas bija 345-644 U/mL (mūsu pētījumā $1644 \mathrm{U} / \mathrm{mL}$ ), arī jutība pēc mūsu datiem bija zemāka visiem rādītājiem, bet specifiskums - līdzīgs. Šajos pētījumos konstatēts, ka zemlīknes laukums CEA punktātā ir 0,74-0,92 (pēc mūsu datiem - 0,72), bet CA 125 punktātā - 0,78 0,85 (pēc mūsu datiem - 0,75). Zemlīknes laukums CEA serumā - 0,79 (pēc mūsu datiem -0,57), bet CA 125 serumā-0,78-0,85 (pēc mūsu datiem-0,706), kas kopumā ir salīdzināmi rādītāji.

Mūsu aprēḳinos vislielākais zemlīknes laukums bija CA 125 līmenim punktātā $(0,751)$ nevis serumā $(0,706)$ vai attiecībai punktāts / serums $(0,606)$, kas liek domāt par CA 125 lokālu sintēzi gan bojātās mezotēlija šūnās, gan arī malignās šūnās. Ca 125 augstā pleiras punktāta / seruma attiecība $(\geq 10,61)$ maligniem eksudātiem salīdzinot ar citas etiologijas šķidrumu pleiras dobumā varētu liecināt par ierobežotu sistēmisku difūziju.

Zemlīknes laukums CEA līdzīgi kā CA 125 vislielākais bija pleiras punktātā - 0,720, bet, atšķirībā no CA 125, arī punktāta / seruma attiecībai bija salīdzinoši liels AUC - 0,715, kas arī varētu liecināt vairāk par lokālu produkciju nekā sistēmisku difūziju.

Nguyen ar kolēgiem (2015) veica 49 pētījumu metaanalīzi. Tika iekḷauti 37 gadījumu kontroles pētījumi, no tiem 33 pētîjumi bija prospektīvi, bet 25 pētījumos tika ņemti pleiras šķidruma paraugi no secīgi stacionētiem pacientiem. Vidējais pacientu skaits pētījumā bija 140 pacienti (25-654). Visos pētījumos MPE tika apstiprināts ar pozitīvu citologiju, pleiras biopsiju vai autopsiju. Apvienotā jutība un specifiskums MPE diagnostikā attiecīgi bija: CEA 54,9 un 96,2\%; CA 15-3 50,7 un 98,3\%; CA 19-9 37,6 un 98,0\%; CA 125 - 57,5 un 92,8\%; CYFRA 62,5 un 93,2\%. salīdzinot ar šo metaanalīzi, aprēḳinātās vērtības ir ḷoti līdzīgas - CEA jutība pie mediānās vērtības bija 50,7, bet specifiskums - 
94,8, savukārt CA 125 attiecīgi - 53,7 \% un 96,1 \%. Autori secināja, ka, kaut gan visiem marķieriem ir augsts specifiskums, tomēr zemā jutība ierobežo šo marḳieru rutīnas lietošanu klīniskajā praksē. Marḳieru kombinēšana uzlabo jutību.

Retrospektīvi analizēti dati par 2115 pacientiem (85 gadus veci un vecāki) - šiem hospitalizētajiem pacientiem tika klīniski un ehokardiogrāfiski apstiprināta sirds mazspēja, serumā noteikti audzēju marḳieri, ts.k., CA 125 un NT-proBNP un atzīmēta perifēras tūskas un transudātu esamība, pacienti tika apsekoti pēc 180 dienām. CA 125 un NT-proBNP līmenis statistiski ticami pieauga, palielinoties sirds mazspejas pakāpei, turklāt tika konstatēta lineāra korelācija starp abiem šiem marķieriem $(\mathrm{r}=5103, \mathrm{p}=0,05)$. CA 125 vidējais līmenis serumā bija statiski ticami augstāks pacientiem ar transudātu pleiras dobumā salīdzinājumā ar pacientiem bez transudāta (108,5 U/L vs 12,1 U/L) un pacientiem ar perifēru tūsku salīdzinājumā ar pacientiem bez perifēras tūskas (78,4 U/L vs 11,9 U/L). 180 dienu laikā 305 pacientiem tika konstatēta kardiāla nāve, bet 461 pacients tika atkārtoti hospitalizēts. Šiem pacientiem CA 125 bija statistiski ticami augstāks nekā pārējiem pacientiem - 78,2 U/L vs 11,7 U/L. Kaplāna - Maiera līknes demonstrēja būtisku atšķirību pacientiem ar normālu un pacientiem ar paaugstinātu CA 125 līmeni serumā. Par pārējiem audzēja marḳieriem šādus statistiski ticamus datus nekonstatēja. Izskaidrojumu šādiem rezultātiem pētnieki pagaidām nevar formulēt (Ma et al., 2013). Mūsu aprēḳini gan liecina, ka CA 125 līmenis MPE statistiski ticami atšķiras no paprapneimonisku pleirītu un kardiālu hidrotoraksu līmeņa gan punktātā, gan serumā, bet nav statistiski ticamas atšķirības starp CA 125 līmeni kardiāla hidrotoraksa un parapneimoniska pleirīta grupās ne punktātā $(p=0,850)$, nedz arī serumā $(\mathrm{p}=0,694)$. 


\subsubsection{BNP}

Marinho un kolēgi 2011. gadā salīdzinājuši kardiālu hidrotoraksu (34 pacienti) ar hepātisku hidrotoraksu (10 pacienti), l,aundabīgu eksudātu (21 pacients) un tuberkulozu pleirītu (12 pacienti). Konstatēts, ka robežvērtības sirds mazspējas diagnostikā bija $132 \mathrm{pg} / \mathrm{ml}$ seruma BNP līmenim (jutība 97,1\%, specifiskums 97,4\%) un $127 \mathrm{pg} / \mathrm{ml}$ pleiras šķidrumam (jutîba 97,1\%, specifiskums 87,8\%), tāpēc secināts, ka BNP līmenis gan serumā, gan pleiras šķidrumā ir noderīgs marķieris sirds mazspējas diagnostikā (Marinho et al., 2011).Mūsu pētījumā jutība gan puntkātā, gan serumā bija ievērojami mazāka (abos subtrātos 50\%), bet specifiskums līdzịgs - 97,3 pleiras punktātā un 95,9\% serumā, arī robežvērtības bija būtiski augstākas - 1097 pg/ml punktātam un 1631 $\mathrm{pg} / \mathrm{ml}$ serumam.

10 pētījumu metaanalīzē, kurā kopumā iekḷauti 1120 pacienti, kardiālu hidrotoraksu identificēšanā NT-proBNP kopējā jutība un specifiskums bija 94\%, pozitīvā paredzes vērtība 15,2 un negatīvā paredzes vērtība - 0,06. Pēc autoru datiem, vairāk kā $85 \%$ sirds mazspējas pacientiem, kuru pleiras dobuma škidrums pēc Laita kritērijiem atbilda eksudātam, bija augsta NT-proBNP koncentrācija. BNP diagnostiskā vērtība, pēc autoru secinājumiem, bija zemāka kā NT-proBNP diagnostiskā vērtība, tāpēc tika ieteikts izmantot NT-proBNP (Porcel et al., 2007).

Kolditz un kolēgi apsekojuši 93 pacientus, 73\% no tiem ar kardiālu hidrotoraksu. Nosakot NT-proBNP līmeni pleiras punktātā un serumā, konstatēts, ka kardiāla hidrotoraksa gadījumos tas ir statistiski ticami paaugstināts, turklāt šì marķiera līmenis serumā un pleiras punktātā cieši korelēja - Spīrmena korelācijas koeficients bija 0,963, p<0,001 (Kolditz et al., 2006). Mūsu pētîjumā, analizējot ROC līknes, konstatēts, ka zemlīknes laukums gan pleiras punktātam, gan serumam ir 0,921, kas norāda uz augstu diagnostiskās metodes jutību un specifiskumu abos substrātos, tāpēc, iespējams, BNP tests 
asins serumā ir pietiekams, lai diagnosticētu vai izslēgtu kardiālas etiologijas transudātu pleiras dobumā, līdz ar to pasargājot pacientu no nevajadzīgas invazīvas iejaukšanās un optimizējot izmeklējumu izmaksas.

\subsubsection{PAI-1}

Pētījumu, kas analizētu PAI-1 nozīmi pleiras punktātā, ir maz. 1995. gadā 10 pacientiem ar empiēmu, 9 - ar tuberkulozu pleirītu, 31 - ar MPE un 3 ar neskaidras etioloǵijas šķidrumu pleiras dobumā tika noteikti PAI-1 un D dimēri gan plazmā, gan pleiras punktātā. Tika konstatēts, ka gan D dimēru, gan PAI-1 līmenis pleiras punktātā ir augstāks nekā plazmā. Pacientiem ar tuberkulozi un empiēmu PAI-1 līmenis bija augstāks nekā pacientiem ar kardiālu transudātu vai MPE (Philip-Joët et al., 1995), kas pilnībā atbilst mūsu datiem, kuros pierādīts, ka PAI-1 līmenis parapneimoniskos eksudātos ir statistiski ticami augstāks nekā malignos eksudātos un kardiālos transudātos.

Pētījumā ar 19 tuberkuloza pleirīta, 29 MPE, 30 parapneimoniska pleirīta pacientiem pleiras punktātā papildus citiem marḳieriem tika noteikti arī PAI-1. Atkarībā no šķidruma izvietojuma pleiras dobumā pacienti tika iedalīti divās grupās - norobežots (42 pacienti) un brīvs šḳidrums pleiras dobumā (36 pacienti). Grupā ar norobežotu šķidrumu pleiras dobumā bija ievērojami augstāks PAI-1 līmenis - 114,9 vs 94,1 pg/ml; p = 0,019. Acīmredzot, paaugstināts PAI-1 norāda uz samazinātu fibrinolīzi norobežotos škiidrumos (Chung et al., 2005). Citā pētījumā 64 parapneimoniska pleirīta pacienti tika sadalīti divās grupās - nekomplicēts (26 pacienti) un komplicēts - norobežots (38 pacienti) parapneimonisks pleirīts. Nekomplicētā parapneimoniskā pleirītā PAI-1 līmenis bijs 43 pg/ml, bet komplicētā - 104 pg/ml (p<0,01), kas arī norāda uz samazinātu fibrinolītisko aktivitāti pleiras dobumā fibrīna septu veidošanās laikā (Chung et al., 2013). Mūsu gadījumā pacienti netika dalīti atkarībā no šķidruma norobežošanās pleiras dobumā, bet pacientiem ar parapneimonisku 
pleirītu, kuriem bija raksturīgāka fibrīna veidošanās un šķidruma norobežošanās, mediānais PAI-1 līmenis bija statistiski ticami augstāks - $291 \mathrm{ng} / \mathrm{ml}, \mathrm{p}<0,001$.

Kopumā parapneimoniskiem pleirītiem raksturīga fibrīna veidošanās un šķidrumam ir tendence norobežoties, lokalizējot procesu. Līdz šim veiktie pētījumi parādījuši, ka iekaisīga rakstura šķidrumos tiešām ir paaugstināts PAI1 līmenis, kas sekmē fibrinolīzes inhibīciju un veicina fibrīna veidošanos (Idell et al., 1991, Lin et al., 2005). Tas nozīmē, ka, iespējams, PAI-1 pastiprinātu veidošanos ietekmē iekaisuma process. Arī mūsu pētījums parādīja, ka parapneimoniskos eksudātos PAI-1 līmenis ir būtiski augstāks kā malignos eksudātos.

Maligniem pleiras eksudātiem nav tendence norobežoties, kas liecina par to, ka tajos fibrīns parasti neveidojas vai veidojas maz, kas varētu būt saistīts ar vidēju PAI-1 aktivitāti (Lin et al., 2005, Lu et al, 2008). Mūsu iegūtie dati liecina par ievērojami zemāku PAI-1 līmeni malignos pleiras eksudātos salīdzinot ar parapneimoniskiem eksudātiem - $188 \mathrm{ng} / \mathrm{ml}$ un $291 \mathrm{ng} / \mathrm{ml}, \mathrm{p}<0,001$. Pēc mūsu domām, PAI-1 vidēji augstais līmenis MPE nesekmē fibrīna veidošanos un šḳidruma norobežošanos līdzīgi kā parapneimoniskiem pleirītiem, bet gan veicina patoloǵiskā procesa izplatīšanos. Atklāts paliek jautājums par to, kas inhibē PAI-1 veidošanos MPE un kā to varētu novērst. Tā kā MPE paliatīvās ārstēšanas pamatā ir procesa norobežošana ar jatrogēni izraisītu fibrīna izgulsnēšanos, tad, iespējams, atbilde uz šo jautājumu varētu uzlabot MPE ārstēšanas taktiku.

Pēc mūsu datiem, arī serumā PAI-1 līmenis bija statistiski ticami augstāks parapneimoniskiem pleirītiem nekā MPE un kardiāliem transudātiem (204 ng/ml, p attiecīgi 0,003 un < 0,001), kas liecina par šī fibrīna inhibitora sistēmisku darbību. 


\subsection{Pētījuma rezultātus ietekmējoši faktori}

Pētījuma rezultātus un to interpretāciju ir ietekmējuši vairāki faktori retrospektīvi analizējot pacientu medicīniskās kartes, varējām spriest tikai pēc ārstējošo ārstu ierakstiem un izmeklējumu rezultātiem, kas atrodami vēsturē, līdz ar to datu kvalitāte zināmā mērā bija atkarīga no medicīniskās dokumentācijas noformēšanas kvalitātes. Prospektīvajā daḷā tika analizēti tikai pacienti, kas nokḷuva Pulmonologiijas nodaḷāa, līdz ar to pētījumā netika iekḷauti pacienti ar citu etiolog̣iju šķidrumiem pleiras dobumā (hepatisks hidrotorakss, hidrotorakss hiperhidratācijas vai nefrotiskā sindroma dēḷ, pleirīti vēdera dobuma patologijas dēḷ, PATE pleirīti u.c.).

Laboratoro rādītāju interpretāciju, iespējams, varēja ietekmēt paraugu nogādāšanas laboratorijā laiks un to analizēšanas ātrums, kas nebija no mums atkarīgs.

Rezultātu interpretāciju ietekmē arī relatīvi nelielā prospektīvi pētīto pacientu grupa, kā arī tas, ka nebija iespējas pacientiem veikt torakoskopijiu un apstiprināt MPE diagnozi arī histologiski. 


\section{SECINĀJUMI}

1. SIA RAKUS stacionāra "Gaiḷezers" visās iekšḳīgo slimību profila nodaḷās visbiežākā pleiras šķidruma etioloǵija bija sirds mazspēja, bet plaušu slimību profila nodaḷā - maligns pleiras eksudāts.

2. Pacientu ar šḳidrumu pleiras dobumā hospitālā mirstība ir trīs reizes augstāka nekā visiem stacionāra pacientiem kopumā.

3. SIA RAKUS staciponāra “Gaiḷezers” iekšḳīgo slimību profila nodaḷās pleiras šķidrumu izmeklēšanas metodes analizētajā periodā bija nepietiekamas salīdzinot ar vadlīnijās un medicīnas literatūrā rekomendētām metodēm.

4. CA 125 noteikšana pleiras punktātā var kalpot kā vērtīgs papildus diagnostisks marḳieris malignu pleiras eksudātu diferencēšanā no citu etiologiju šķidrumiem pleiras dobumā

5. PAI-1 līmenis malignos pleiras eksudātos bija statistiski ticami zemāks nekā parapneimonisku pleirītu gadījumos un tas varētu liecināt par procesa izplatības tendenci ḷaundabīgu slimību gadījumos, tāpēc būtu vērtīgi tālāki fibrinolīitiskās sistēmas aktivitātes pētījumi MPE.

6. Kardiāla hidrotoraksa diferencēšanai informatīvs marķieris ir BNP asins serumā, BNP pleiras punktātā papildus diagnostisku informāciju nesniedz. 


\section{PRAKTISKĀS REKOMENDĀCIJAS}

Lai uzlabotu pleiras dobuma šķidruma diagnostiku, diferenciāldiagnostiku un atvieglotu savlaicīgu un maksimāli efektīvu ārstēšanu, nepieciešams:

1. Visiem pacientiem, kuriem klīniskā aina neliecina par patoloǵiju, kura komplicējas ar transudātu pleiras dobumā (dekompensēta sirds mazspēja, dekompensēta aknu mazspēja, hroniska nieru slimība) un kuriem ir šķidrums pleiras dobumā patologiskā daudzumā, nepieciešama pleiras dobuma punkcija ar pirmspunkcijas ultrasonoskopiju.

2. Minimālais laboratoro izmeklējumu daudzums:

a. LDH un olbaltumvielu noteikšana pleiras punktātā un serumā;

b. citologiskā pleiras punktāta izmeklēšana.

3. Lai pierādītu kardiālu transudātu, jānosaka BNP vai NT-pro-BNP asins serumā.

4. Ja ir aizdomas par MPE, bet citologija ir negatīva un nav pieejama torakoskopija, pleiras punktātā var noteikt CA 125. 


\section{IZMANTOTĀS LITERATŪRAS SARAKSTS}

1. Akturk, U. A., Ernam, D., Akbay, M. O. et al., 2016. Role of the NeutrophilLymphocyte Ratio in the Differential Diagnosis of Exudative Pleural Effusion. Clinics (Sao Paulo). Iegūts no: https://www.ncbi.nlm.nih.gov/pmc/articles/PMC50 54976/ (sk. 04.02.2017.)

2. Altman, D. G., 1997. Practical Statistics for Medical Research. London, Chapman \& Hall.

3. Anevlavis, S., Kouliatsis, G., Sotiriou, I. et al., 2014. Prognostic factors in patients presenting with pleural effusion revealing malignancy. Respiration. Iegūts no: ttp: //search.proquest.com.db.rsu.lv/docview/1531631902?accountid=32932 (sk.05.02.2017)

4. Antonangelo, L., Sales, R. K., Corá, A. P. et al., 2015. Pleural fluid tumour markers in malignant pleural effusion with inconclusive cytologic results. Curr Oncol. Iegūts no: https://www.ncbi.nlm.nih.gov/pmc/articles/PMC4608406/ (sk. 26.08.2016.).

5. Antony, V. B., Loddenkemper, R., Astoul, P. et al., 2001. Management of malignant pleural effusions. Eur Respir J. Iegūts no: http://erj.ersjournals.com/content/18/2/ 402.long\#T1 (sk. 09.08.2016.).

6. Bielsa. S, Porcel. J. M., Castellote, J., 2012. Solving the Light's criteria misclassification rate of cardiac and hepatic transudates. Respirology. 17(4): 721726.

7. Broaddus, V. C., Light, R. W., 2016. Pleural effusion. No: Broaddus, V. C., Mason, R. J., Ernst, J. D. et al. Murray and Nadels Textbook of Respiratory Medicine. $6^{\text {th }}$ ed. Elsevier. Iegūts no: https:/www-clinicalkey-com.db.rsu.lv/\#!/content/book/3s2.0-B9781455733835000798 (sk. 06.08.2016.)

8. Bunjhoo, H., Wang, Z. Y., Chen, H. L., 2012. Diagnostic value of interleukin 21 and carcinoembryonic antigen levels in malignant pleural effusions. Asian Pac J Cancer Prev. Iegūts no: http://journal.waocp.org/article_26692_aaf0b49d3b2cc70 97fbca0a5e6c4fe85.pdf (sk. 04.02.2017.)

9. Choi, W. I., Qama, D., Lee, M. Y. et al., 2013. Pleural cancer antigen-125 levels in benign and malignant pleural effusions. Int J Tuberc Lung Dis. Iegūts no:

http://docserver.ingentaconnect.com/deliver/connect/iuatld/10273719/v17n5/s23.p df? expires $=1472295620 \&$ id $=88480205 \&$ titleid $=3764 \&$ accname $=$ GGues + User \&c hecksum=4EDAA1630E52CF24C7F2F5A0B3EBCDB4 (sk. 27.08.2016.).

10. Chung, C. L., Chen, C. H., Sheu, J. R. et al., 2005. Proinflammatory cytokines, transforming growth factor-beta1, and fibrinolytic enzymes in loculated and freeflowing

pleural exudates. Chest. Iegūts no: http://www.sciencedirect.com.db.rsu.lv/science /article/pii/S0012369215500012 (sk. 27.08.2016.).

11. Chung, C. L., Hsiao, S. H., Hsiao, G. et al., 2013. Clinical importance of angiogenic cytokines, fibrinolytic activity and effusion size in parapneumonic effusions. PLoS One. Iegūts no: https://www.ncbi.nlm.nih.gov/pmc/articles/PMC3538784/\#pone.0 053169-Cameron1 (sk. 28.08.2016.).

12. Clive, A. O., Kahan, B. C., Hooper, C. E. et al., 2014. Predicting survival in malignant pleural effusion: development and validation of the LENT prognostic 
score. Thorax. Iegūts no: https://www.ncbi.nlm.nih.gov/pmc/articles/PMC425130 6/ (sk. 27.08.2006.).

13. Dara, M., Dadu, A., Kremer, K et al., 2013. Epidemiology of tuberculosis in WHO European Region and public health response. Eur Spine J. 22(4) 549-555.

14. Davies, H. E., Davies, R.J., Davies, C. W., 2010. BTS Pleural Disease Guideline Group.Management of pleural infection in adults: British Thoracic Society Pleural Disease Guideline 2010. Thorax. Iegūts no: https://www.britthoracic.org.uk/document-library/clinical-information/pleural-disease/pleuraldisease-guidelines-2010/pleural-disease-guideline/ (sk. 31.01.2017.).

15. Dawson, B., Trapp, R. G., 2001. Basic \& Clinical Biostatistics. New York, Lange Medical Books/McGraw-Hill.

16. Feller-Kopman, D. J., Reddy, C. B., DeCamp, M. M. et al., 2018. Management of Malignant Pleural Effusions. An Official ATS/STS/STR Clinical Practice Guideline. Am J Respir Crit Care Med. 198(7): 839-849.

17. Feng. M., Zhu. J., Liang. L. et al., 2016. Diagnostic value of tumor markers for lung adenocarcinoma-associated malignant pleural effusion: a validation study and metaanalysis. Int J Clin Oncol. Iegūts no: http://link.springer.com/article/10.1007\%2Fs 10147-016-1073-y (sk. 04.02.2017.).

18. Gu, Y., Zhai, K., Shi, H. Z., 2016. Clinical Value of Tumor Markers for Determining Cause of Pleural Effusion. Chin Med J (engl). Iegūts no: https://www.ncbi.nlm.nih .gov/pmc/articles/PMC4799566/ (sk. 04.02.2017.)

19. Havelock, T., Teoh, R., Laws, D. et al., 2010. Pleural procedures and thoracic ultrasound: British Thoracic Society pleural disease guideline 2010. Iegūts no: htt p://thorax.bmj.com/content/65/Suppl_2/i61.full.pdf+html (sk. 09.08.2016.).

20. Hooper, C., Lee, Y. C., Maskell, N., 2010. BTS Pleural Guideline Group. Investigation of a unilateral pleural effusion in adults: British Thoracic Society Pleural Disease Guideline 2010. Thorax. Iegūts no: https://www.britthoracic.org.uk/document-library/clinical-information/pleural-disease/pleuraldisease-guidelines-2010/pleural-disease-guideline/ (sk. 17.08.2016.).

21. Huggins, J. T., Sahn, S. A., Doelken, P., 2011. Thoracenthesis. No: Vincent, J. L., Abraham, E., Kochanek, P. et al. Textbook of ciritical care. $3^{\text {rd }}$ ed. Saunders. Iegūts no: https://www-clinicalkey-com.db.rsu.lv/\#!/content/book/3-s2.0-

B9781437713671002391 (sk. 08.08.2016.).

22. Idell, S., Girard, W., Koenig, K. B., Mclarty, J., Fair, D. S., 1991. Abnormalities of pathways of fibrin turnover in the human pleural space. Am. Rev. Respir. Dis. 144: 187-194.

23. Kao, S.C., Pavlakis, N., Harvie, R. et al. 2010. High blood neutrophil-to-lymphocyte ratio is an indicator of poor prognosis in malignant mesothelioma patients undergoing systemic therapy Clin Cancer Res. Iegūts no: http://clincancerres.aacrjournals.org/content/16/23/5805.long (sk. 05.02.2017.).

24. Kolditz, M., Halank, M., Schiemank, C.S. et al. 2006.High diagnosticē accuracy of NT-proBNP for cardiac origin of pleural effusions Eur Resp J., 28(1): 144-150.

25. Light, R. W.; Lee, Y. G 2003. Textbook of pleural diseases Edward Arnold (Publishers) Ltd., 553.

26. Light, R.W. 2013.The Light criteria Clinics in Chest Medicine. 34(1). Iegūts no: https://www-clinicalkey-com.db.rsu.lv/\#!/content/journal/1-s2.0-

S0272523112001244 (sk. 17.08.2016.). 
27. Lin, F.C., Chen, Y.C., Chen, F.J., Chang, S.C. 2005. Cytokines and fibrinolytic enzymes in tuberculos and parapneumonic effusions. Clin Immunol. Aug;116(2): 166-173.

28. Loddenkemper, R., Antony, V. B. 2002. Pleural diseases. European Respiratory Society Journals Ltd. 326.

29. Ma, J., Zhao, Y., Wang, Y. et al. 2013. Tumor marker levels in patients aged 85 years and older with chronic heart failure. Eur J Intern Med. Iegūts no: http://ac.elscdn.com.db.rsu.lv/S0953620513001052/1-s2.0-S0953620513001052-

main.pdf?_tid=9cc65c38-6c36-11e6-9463-

00000aacb35e\&acdnat=1472289429_c50887a835100dec7a0314e914e20d87 (sk. 27.08.2016.).

30. Marel, M., Zrustova, M., Stasny, B. et al. 1993. The incidence of pleural effusion in a well-defined region: epidemiologic study in central Bohemia Chest . Iegūts no: http://www.sciencedirect.com/science/article/pii/S0012369215422974

(sk. 09.08.2016.).

31. Marinho, F. C. A., Vargas, F. S., Fabri Jr. et.al. 2011. Clinical usefulness of B-type natriuretic peptide in the diagnosis of pleural effusions due to heart failure Respirology. 16 (3): 495-499.

32. Mohanty, S., Kapil, A., Das, B.K. 2007. Bacteriology of parapneumonic pleural effusions in an Indian hospital Trop Doct. Iegūts no: https://www.ncbi.nlm.nih.gov/pubmed/17988487 (sk. 07.02.2017.).

33. Nguyen, A.H., Miller, E.J., Wichman, C.S. et al. 2015. Diagnostic value of tumor antigens in malignant pleural effusion: a meta-analysis. Transl Res. Iegūts no: http://ac.els-cdn.com.db.rsu.lv/S1931524415001139/1-s2.0-S1931524415001139main.pdf?_tid=8977bfe8-6bcb-11e6-9ccc00000aacb362\&acdnat=1472243441_0a8b4c17944cbb73f920a1250b0fb88e （sk. 26.08.2016.).

34. Philip-Joët, F., Alessi, M.-C., Philip-Joët, C. et al. 1995. Fibrinolytic and inflammatory processes in pleural effusions Eur Respir J. Iegūts no: http://erj.ersjournals.com/content/erj/8/8/1352.full.pdf (skat. 27.08.2016.).

35. Porcel, J.M., Vives, M., Cao, G. et al. 2004. Measurement of pro-brain nariuretic peptide in pleural fluid for the diagnosis of pleural effusions due to heart failure. $\mathrm{Am}$ J Med. Iegūts no: http://www.amjmed.com/article/S0002-9343(03)00716-2/fulltext (sk. 17.08.2016.).

36. Porcel, J. M., Chorda, J., Cao, G. et.al. 2007. Comparing serum and pleural fluid pro-brain natriuretic peptide (NT-proBNP) levels with pleural-to-serum albumin gradient for the identification of cardiac effusions misclassified by Light's criteria. Respirology, 12 (5): 654.

37. Roberts, M.E., Neville, E., Berrisford, R.G. et al. 2010. BTS Pleural Disease Guidline Group. Management of a malignant pleural effusion: British Thoracic Society Pleural Disease Guidline 2010. Thorax. Iegūts no: http://thorax.bmj.com/c ontent/65/Suppl_2/ii32/T1.expansion.html (sk. 12.08.2016.).

38. Sahn, A.S. 2003. Approach to the patient with a pleural effusion In: Light, R. W., Lee, Y. G. ed. Textbook of pleural diseases. London: Edward Arnold (Publishers) Ltd. 183-190. 
39. Sahn, S.A. 1997. Pleural diseases related to metastatic malignancies. Eur Respir J. 10. Iegūts no: http://erj.ersjournals.com/content/erj/10/8/1907.full.pdf (sk. 08.08.2016.).

40. Sharma, S.K., Bhat, S., Chandel, V.et al. 2015. Diagnostic utility of serum and pleural fluid carcinoembryonic antigen, and cytokeratin 19 fragments in patients with effusion from nonsmall cell lung cancer. J Carcinog. Iegūts no: https://www. ncbi.nlm.nih.gov/pmc/articles/PMC4736054/\#ref8 (sk. 26.08.2016.).

41. Slimību profilakses un kontroles centrs, 2015. Veselībs aprūpes statistika. Iegūts no: https://www.spkc.gov.lv/lv/statistika-un-petijumi/statistika/veselibas-aprupesstatistika1/get/nid/1 (sk. 31.01.2017.).

42. Son, S.M., Han, H.S., An, J.Y. et al. 2015. Diagnostic performance of CD66c in lung adenocarcinoma-associated malignant pleural effusion: comparison with CEA, CA 19- 9, and CYFRA 21- 1. Pathology. Iegūts no: https://www.clinicalkey- com. db.rsu.lv/service/content/pdf/watermarked/1-s2.0S0031302516301416.pdf?locale=en_US (sk. 04.02.2017.).

43. Teibe,U. 2007. Bioloğiskā statistika: mācību materiāls. Rīga, LU Akadēmiskais apgāds.

44. Valdes, L., Alvarez, D., Valle, J.M. et al. 1996. The aetiology of pleural effusions in an area with high incidence of tuberculosis. Chest. Iegūts no: http://www.scienc edirect.com/science/article/pii/S0012369215455461 (sk. 09.08.2016.).

45. Vaz, M.A., Teixeira, L.R., Vargas, F.S. et al. 2001. Relationship between pleural fluid and serum cholesterol levels. Chest. 119(1): 204-210.

46. Villena Garrido, V., Cases, Viedma, E., Fernández Villar, A. et al. 2014. Recommendations of diagnosis and treatment of pleural effusion. Update Arch Bronconeumol. Iegūts no: http://www.archbronconeumol.org/index.php?p=water mark\&idApp=UINPBA00003Z\&piiItem $=$ S1579212914001293\&origen=bronco $\&$ web=bronco\&urlApp=http://www.archbronconeumol.org\&estadoItem=S300\&idio maItem=en (sk. 28.07.2016.).

47. Villena Garrido. V., Lopez Encuentra. A., Echave-Sustaeta. J. et al. 2002. Estudio prospective de 1000 pacientes consecutivos con derrame pleural. Etiologia del derrame y characteristicasnde los pacientes. [Prospective study of 1000 consecutive patients with pleural effusion. Etiology of the effusion and characteristics of the patients.]. Arch Bronconeumonol. 2002; 38 (1): 21-26.

48. Xu, C.H., Zhan, P., Yu, L.K.2014. Diagnostic value of pleural interleukin 17 and carcinoembryonic antigen in lung cancer patients with malignant pleural effusions. Tumour Biol. Iegūts no: http://eds.b.ebscohost.com.db.rsu.lv/eds/pdfviewer/pdfvie wer?vid $=5 \&$ sis $=96 \mathrm{ab} 283 \mathrm{a}-378 \mathrm{~d}-4 \mathrm{~d} 7 \mathrm{~d}-80 \mathrm{~d} 2$ 80be6f009359\%40sessionmgr101\&hid=119 (sk. 04.02.2017.).

49. Zablockis R., Nargela R. 2002. Diagnostic value of pleural fluid citologic examination. Medicina (Kaunas). 38(12): 1171-1178.

50. Zissimopoulos, A., Stellos, K., Permenopoulou, V. et al. 2007. The importance of the tumor marker CYFRA 21-1 in patients with lung cancer after surgery or chemotherapy. Hell J Nucl Med. 10: 62-66. 


\section{PUBLIKĀCIJAS PAR PĒTİJUMA TĒMU}

\section{Zinātniskie raksti}

1. Dubava, D. (Žentiņa), Valdmane, A., Vikmane, I., Lejnieks, A., 2011. Pleiras izsvīduma diagnostika Rīgas Austrumu klīniskās universitāte slimnīcas stacionārā "Gaiḷezers". Rīgas Stradiņa universitātes Zinātniskie raksti. (1); 59.-70. lpp.

2. Dubava, D. (Žentiņa), Tirzìte, M., Krams, A., Lejnieks, A., 2012. Audzēja marķieri pleiras šķidrumā. Rīgas Stradiṇa universitātes Zinātniskie raksti. (1); 65.-71. lpp.

3. Dubava, D. (Žentiņa), Bočins, R., Stuḳēna, I., Krams, A., Lejnieks, A., 2013. Vai BNP līmenis serumā ir pietiekami jutīgs diagnostisks marķieris pacientiem ar kardiālu hidrotoraksu? Rīgas Stradiṇa universitātes Zinātniskie raksti. (1); 75.-81. lpp.

4. Zentina, D., Stukena, I., Grinberga, S., Krams, A., Lejnieks, A. 2016. Diagnostic Value of tumor markers Ca 125 and CEA in the diagnostics of malignant pleural fluids. Proceedings of the Latvian Academy of Sciences, Section B, (70). 2(701): 41-46. DOI: 10.1515/prolas-20160008.

5. Zentina,D., Stukena, I., Krams, A., Lejnieks, A. 2019. PAI-1 Level Differences in Malignant Plural Effusion, Parapneumonic Pleuritis, and Cardiac Hydrothorax. Medicina (Kaunas). 55(9). pii: E567. doi: 10.3390/medicina55090567. PubMed PMID: 31487930.

\section{Tēzes starptautiskās konferencēs}

1. Dubava, D. (Žentiņa), Tirzite, M., Stukena, I., Krams, A., Lejnieks, A. Potential role of antioxidant status ratio in differential diagnosis of pleural effusion European Respiratory Society Annual Congress. Barcelona, 2013. (Poster Discussion). 


\section{Tēzes konferencēs Latvijā}

1. Dubava, D. (Zentina), Krams, A., Lejnieks, A. Leikocītu procentuālā sastāva nozīme maligna pleiras eksudāta diagnostikā. Rīgas Stradiṇa universitātes Zinātniskās konferences tēzes. Rīga, 2012. 254. lpp. (Stenda referāts).

2. Dubava (Žentiņa), D., Tirzīte, M., Stuḳēna, I., Krams, A., Lejnieks, A. 2013.Totālā antioksidantu statusa noteikšanas prognostiskas izmantošanas iespējas pleiras šķidrumu diagnostikā. Rīgas Stradiņa Universitātes Zinātniskās konferences tēzes. Rīga, 2013. 278. lpp. (Stenda referāts).

3. Dubava (Žentiņa), D., Bočins, R., Stuķēna, I., Krams, A., Lejnieks, A. B-tipa nātrijurētiskais peptīds asins serumā un pleiras punktātā papildu kritērijs pleiras šķidrumu diferenciālajā diagnostikā. Rīgas Stradiņa universitātes Zinātniskās konferences tēzes. Rīga, 2013. 40. lpp. (Mutiska uzstāšanās).

4. Žentiņa, D., Stuķēna, I., Krams, A., Lejnieks, A. Vai pēc seruma iekaisuma marḳieriem - laktātdehidrogenāzes un C reaktīvā olbaltuma - var spriest par pleiras šķidruma etioloǵiju? Rīgas Stradina universitātes Zinātniskās konferences tēzes. Rīga, 2014. 273. lpp. (Stenda referāts).

5. Vasiljeva, G., Stuķēna, I., Žentiņa, D., Krūmiņa, A. Sliktas prognozes riska faktori pacientiem ar sadzīvē iegūtu pneimoniju. Rīgas Stradiṇa universitātes Zinātniskās konferences tēzes. Rīga, 2014. 151. lpp. (Stenda referāts).

6. Žentiņa, D., Bočins, R., Stuķēna, I., Krams, A., Lejnieks, A. 2015. Plazminogēna aktivatora inhibitors -1 dažādas etiologijas pleiras šḳidrumā. Rīgas Stradina universitātes Zinātniskās tēzes. Rīga, 2015. 269. lpp. (Stenda referāts). 


\section{PATEICĪBAS}

Visdziḷākā pateicība mana darba vadītājam Dr. med. Profesoram Aivaram Lejniekam par padomiem, pacietību, neatlaidību un pamudinājumiem.

Sirsnīgs paldies manam draugam, kolēgeei un padomdevējai Dr.med. asociētai profesorei Ingai Stuķēnai par nenovērtējamo atbalstu darba tapšanā.

Paldies Dr. Agnesei Valdmanei-Zviedrītei par palīdzību datu apkopošanā.

Paldies maniem lieliskajiem kolēgiem P.Stradiṇa KUS par atbalstu un iedrošinājumu brīžos, kad pietrūka apmṇēmības.

Paldies Roche Akadēmijai par finansiālo atbalstu.

Visbeidzot - paldies manai gimenei, kura ir mana galvenā motivācija sasniegt jaunus mērķus. 